\title{
The Effects of Adaptation Measures on Hurricane Induced Property Losses: Which FEMA investments have the highest returns?
}

\begin{abstract}
This paper evaluates the relative effectiveness of FEMA expenditures on hurricane induced property losses. We find that spending on FEMA ex-ante mitigation and planning projects leads to greater reductions in property losses than spending on ex-post adaptation programs - specifically, a one percent increase in annual spending on ex-ante risk reduction and warning projects reduces damages by 0.21 percent while a one percent increase in ex-post recovery and clean-up spending reduces damages by 0.12 . Although both types of program spending are effective, we find the marginal return from spending on programs that target longterm mitigation and risk management to be almost twice that of spending on ex-post recovery programs. With the predicted increases in the frequency and severity of North Atlantic hurricanes in the future, our findings suggest there are important potential gains that could be realized from the further diversification of FEMA spending across project categories.
\end{abstract}

Keywords: natural disasters, hurricanes, property losses, FEMA, adaptation

JEL Codes: Q54, Q58, H84 


\section{The Effects of Adaptation Measures on Hurricane Induced Property Losses: Which FEMA investments have the highest returns?}

\section{Introduction}

Hurricanes are one of the costliest natural phenomena in the United States. Although hurricane fatalities have become less of a concern over time, partially due to improved warning and weather forecasting systems in coastal counties (Sadowski and Sutter, 2005), the declining trend in loss of human life has not been accompanied by a decrease in property damage (Sheets and Williams, 2001). Increased population, rising standards of living and the consequent accumulation of wealth in U.S. coastal areas have contributed to rising property losses as a result of hurricanes (Pielke et al., 2008). Over time, with continued increases in coastal development coupled with projected increases in hurricane intensities as a result of climate change, damage figures will likely increase substantially unless actions are taken to curb coastal development and improve existing building standards (Pielke et al., 2008; Mileti, 1999; Emanuel, 2013).

The U.S federal government spends millions of dollars on hazard mitigation projects to protect communities from natural disasters and public assistance projects to help disaster impacted communities recover following major disasters. Since 1989, the U.S. Federal Emergency Management Agency (FEMA) has spent more than \$13 billion to help communities implement long-term hazard mitigation projects. Approximately 76 percent of total mitigation grant funding has been allocated for hurricane, storm and flood related disasters. Even more was spent for public assistance projects-i.e., $\sim 50$ billion (in 2005\$) was given to impacted 
communities since 1989, in the form of immediate assistance for disaster recovery. ${ }^{1}$ Approximately 80 percent of these funds were allocated in response to hurricane, flood or severe storm related events. Furthermore, these figures could be higher after accounting for non-disaster government transfer payments (Deryugina, 2011). ${ }^{2}$ The numbers are striking and have elevated public concern especially in the wake of recent studies projecting an increase in the frequency and severity of North-Atlantic basin hurricanes (Emanuel, 2013).

Without empirical evidence, we can say little about how effective these hazard mitigation and public assistance programs are in terms of promoting local resilience. It is reasonable to assume that protective/adaptive measures should mitigate losses; however, their effectiveness might vary depending on the severity of hazard as well as the behavioral responses of private agents. This paper compares the relative effectiveness of pre-disaster risk reduction activities and post-disaster response and recovery assistance by econometrically estimating a model of historical property damages comprising 651 counties along the Atlantic coast that have incurred hurricane-induced property losses at least once during the period 1989-2009.

To compare the relative effectiveness of alternative adaptation policies implemented by federal and local governments, the model includes two FEMA categories as explanatory variables: (1) cumulative spending in ex-ante mitigation and planning programs - e.g. investment in mitigation planning, warning, and awareness studies as well as improvement of structural projects (dams, levees, infrastructure rehabilitation, shoreline and land slide stabilization, relocation, acquisition of structures, and retrofitting projects); and (2) ex-post recovery and clean-up spending from prior incidents. The ex-ante projects are funded through the FEMA Hazard Mitigation Grants Programs, while ex-post projects are funded through the FEMA Public

\footnotetext{
${ }^{1}$ These figures (calculated by the authors) are based on data from the Hazard Mitigation Grant Program (HMGP) and Public Assistance grants programs initiated under the Robert T. Stafford Disaster Relief and Emergency assistance Act (FEMA, 2010a, b, d, e).

${ }^{2}$ Deryugina (2011) estimates that non-disaster transfers could add an additional $\$ 654$ per capita to spending in hurricane impacted counties.
} 
Assistance Grants Program (FEMA, 2010a and 2010b). The model also controls for a county's geophysical exposure to hurricanes and physical vulnerability; economic and demographic exposure; and infrastructure vulnerability.

We estimate the elasticity of FEMA ex-ante program spending to be -0.21 and -0.12 for FEMA ex-post recovery spending -i.e., a one percent marginal increase in hazard mitigation spending is estimated to result in a 0.21 percent decline in property losses while the losses are reduced by 0.12 percent in response to disaster recovery and clean-up spending. Exploring the effects along intensive vs. extensive margins, our results further indicate that ex-ante programs are effective along extensive margins (e.g. reducing the probability of disastrous outcomes), but their effects diminish once damages are realized. FEMA ex-post adaptation programs, on the other hand, are effective across intensive margins (i.e. reduce realized damages). While returns on ex-ante and ex-post investments differ, loss mitigating features of the two types of programs suggest that they can be viewed as substitutes at least in the short-term.

Another implication of our results is that while recovery spending is effective, the marginal return per dollar of investment in recovery spending is almost half that of investing in long-term mitigation programs. Given that current FEMA spending on mitigation programs (planning, warning systems and improvement in structural mitigation) is smaller by an order of magnitude relative to spending on disaster response and clean-up programs, these results suggest that we would expect a significantly larger return on investment if more FEMA spending was redirected to ex-ante mitigation measures at the margin. ${ }^{3}$

The remainder of the paper is organized as follows. In Section 2 we review the literature on the impacts of natural disasters. In Section 3, we identify the determinants of hurricane

\footnotetext{
${ }^{3}$ The extent to which increased spending will continue to give benefits in mitigation measures depends on the rate of diminishing returns, a topic we leave for future research.
} 
damages and develop a conceptual framework in Section 4. Section 5 provides a description of the data used in the analysis and Section 6 describes our empirical estimation strategy. Section 7 presents results and Section 8 presents robustness checks. Section 9 discusses major findings of our study and lastly, Section 10 provides concluding remarks.

\section{Previous studies on the impacts of natural disasters}

Previous studies related to disaster impacts make strong assumptions on adaptation. While some studies ignore adaptation altogether (Nordhaus, 2010), in other cases adaptation is inferred from a time trend or physical exposure (Sadowski and Sutter, 2005; 2008; Hsiang and Narita, 2012). While these studies generally find that communities and countries adapt, they are unable to identify the specific strategies adopted that reduce hazard risk. While studies in the risk and insurance literature have developed theoretical frameworks to differentiate between different types of adaptation measures and assess their effectiveness for loss mitigation (self-insurance, self-protection or market insurance, risk-reducing, risky, etc.), these studies acknowledge the limitations of theoretical assumptions and unequivocally call for an empirical examination of the effectiveness of heterogeneous measures in protecting vulnerable areas (Ehrlich and Becker, 1972; Lewis and Nickerson, 1989; Shogren and Crocker, 1991; Quiggin, 1992).

In addition to offering a much needed empirical examination of the relative effectiveness of alternative adaptation measures, this paper also contributes to the growing literature on climate change adaptation related to natural disasters in a number of ways. First, the vast majority of past studies have focused on understanding vulnerability caused by natural disasters on a global scale. ${ }^{4}$ Commonly, these studies account for income, population, types of hazard as well as proxies for institutional quality (Kahn, 2005; Toya and Skidmore, 2007; Kellenberg and

\footnotetext{
${ }^{4}$ For a brief review of the disaster-related economic literature see Cavallo and Noy (2011) and Kousky (2014).
} 
Mobarak, 2008; Ward and Shively, 2011; Silbert and Useche, 2011; Schumacher and Strobl, 2011). The major finding of previous cross country analyses of disasters indicate that poor (developing) countries are more vulnerable to natural disasters than wealthier countries. However, these studies are limited in that they do not capture adaptation responses at a microlevel, which our study does.

Second, while several papers have investigated disaster vulnerability within a country context and developed indirect/alternative measures of loss mitigation, to our knowledge no study has explicitly measured the relative effectiveness of alternative public adaptation measures, particularly those funded by the federal government. For instance, using decadal dummies, Sadowski and Sutter (2005) infer historical adaptive trends and identify increased wealth exposure to be a consequence of the reduced lethality of hurricanes or so-called "safe hurricanes." In another study (Sadowski and Sutter, 2008), the authors find evidence that damages are reduced in counties with prior land-falling hurricanes, suggesting the existence of local level adaptation as a result of prior exposure. Hsiang and Narita (2012) also show that countries with chronic tropical cyclone exposure suffer fewer damages; however, the effect appears to be small. Unlike these previous studies, we explicitly model the effects of alternative adaptation measures that are funded by the U.S. federal government.

Third, few papers have assessed the effectiveness of adaptation measures to lessen economic damages from flood or other weather related disasters by emphasizing the importance of state involvement in enforcing laws and regulation, building codes and structural measures (Burby, 2005; Brody et al., 2007). Our research complements these previous studies by addressing the problem in a more inclusive framework that includes explicit modeling of a large spectrum of hurricane damage determinants. The wide range of data used in our analysis allows 
us to consider both ex-ante as well as ex-post adaptation policies and compare the relative effectiveness of these alternative loss mitigation investments. Our identification strategy uses political influence exerted by the president as well as senate/house oversight committees responsible for disaster declarations and authorization of FEMA disaster spending to instrument for potential endogeneity in FEMA expenditures.

Finally, exploring the effects along extensive vs. intensive margins we explicitly test for adverse effects as a result of structural projects (dams, levees, etc.) designed to protect vulnerable areas. Adverse effects of structural projects could occur for several reasons. First, if the severity of hazards exceeds the designed capacity of these protective structures, their failure could lead to an even larger catastrophic outcome (Mileti, 1999). Second, providing protective public infrastructure could encourage private development resulting in more wealth exposure to risk which subsequently translates into higher damages in risk prone areas (Kousky, Luttmer and Zeckhauser, 2006; Kousky and Olmstead, 2010). Public disaster relief programs could also lead to perverse incentives. The expectation of post disaster recovery/relief assistance can also lead to risky investments if individuals believe that financial assistance will be supplied if the disaster re-occurs. Heuristic attitudes of individuals to risk and limited financial liability for disaster loss result in an under-investment in private protective measures (Kunreuther, 2001; Lewis and Nickerson, 1989).

\section{Determinants of Hurricane Damages}

Hurricanes are a severe form of tropical cyclone with intensity measured on the SaffirSimpson Hurricane scale. This scale consists of five categories. A Category 1 hurricane is the weakest hurricane with associated wind speeds of 74-95 mph (or 64-82 kt), whereas a Category 5 hurricane is the strongest with wind speeds exceeding $155 \mathrm{mph}$ (greater than $135 \mathrm{kt}$ ). Major 
hazards associated with tropical cyclones are storm surges, high winds, heavy rains/flooding and occasionally tornadoes (NOAA, 1999).

Many researchers argue that climate change may cause changes in hurricane frequency and intensity. Although, results are mixed on a global scale (Webster et al., 2005), many scholars predict that hurricane intensities in the North Atlantic basin will likely increase. Several recent studies employing multi-model ensembles of climate change projections investigate potential future changes in hurricane activities as a result of climate change. Emanuel (2013) shows that under the RCP8.5 climate scenario, the CMIP5 climate model simulations all predict an increase in the frequency of downscaled tropical cyclones during the $21^{\text {st }}$ century. Villarini and Vecchi (2013), using recently developed statistical methods, predict that the North Atlantic Power Dissipation Index (PDI), a metric that combines storm duration, frequency and intensity, will increase by the end of the $21^{\text {st }}$ century. Although Knutson et al (2013), combining a regional atmospheric model for seasonal Atlantic simulations with a hurricane prediction model and several global climate model projections, show a reduction in tropical storm frequency, their results also lead to a general conclusion that intense hurricanes (Category 4 and 5) will likely become more frequent.

The simplest model to predict hurricane induced damages has involved estimating the relationship between damages and a hurricane's sustained maximum wind speed. Using this approach, Emanuel (2005) estimates the actual monetary loss due to wind as a cubic function of maximum wind speed. Nordhaus (2010) estimates the wind power coefficient to be around eight and refers to it as the "eights-power law of damages." These differences appear to be related to 
the choice of normalized damages (Strobl, 2011). ${ }^{5}$ Hsiang and Narita (2012) show that increasing average intensity from a category 1 to category 2 hurricane triples economic impacts.

In addition to wind speed, hurricane damages are greatly exacerbated by population growth, prior patterns of economic development, and existing infrastructure (Pielke and Landsea, 1998; Pielke et al, 2008; Mileti, 1999). Furthermore, the impacts of hazards also depend on socio-economic and infrastructure vulnerability of impacted communities (Cutter, Boruff and Shirley, 2003) along with their ability (private and/or public) to adapt and mitigate these impacts (Davidson and Lambert, 2001). The latter aspect is important, because ignoring adaptation can potentially overstate the economic impacts of these hazards. ${ }^{6}$

\section{Conceptual Framework}

To generate testable hypotheses on the role of FEMA spending in reducing hurricane damages, we develop a simple framework which is adapted from Lewis and Nickerson (1989) who examine the impact of natural hazards on property value and individuals' optimal adaptation behavior under the assumption of limited financial liability of loss. Limited liability is the outcome of disaster relief programs provided by the government in the event of a severe natural disaster. The individual is assumed to be endowed with a certain level of exogenous wealth $(W)$ and property which is exposed to risk.

Property value, $D(x, z, \boldsymbol{T})$, is a function of private self-insurance expenditure $(x)$, severity of hazard $(z)$, and government assistance $(\boldsymbol{T})$. The severity of hazard, $z$, is defined as a random realization of the states of nature with the cumulative distribution function $F(z)$, such

\footnotetext{
${ }^{5}$ Strobl (2011), employing the normalized damages of hurricanes developed by Pielke et al. (2008), shows that the selection of power is sensitive to the choice of normalized damages.

${ }^{6}$ In the disaster literature, adaptation and mitigation are used interchangeably and both are viewed in terms of coping and risk management strategies related to weather extremes such as floods, storms, droughts and other natural hazards (Burton, 1997; see FEMA definition http://www.fema.gov/what-mitigation\#1).
} 
that higher values of $\mathrm{z}$ correspond to more severe states of nature. ${ }^{7} \mathrm{We}$ assume that government assistance $(\boldsymbol{T})$ consists of both ex-ante mitigation and ex-post public assistance expenditures; i.e., $\boldsymbol{T}$ represents a vector of two types of adaptation $\left(T_{1}, T_{2}\right)$.

$D(x, z, \boldsymbol{T})$ is twice continuously differentiable in all arguments and concave with a positive marginal return on both private and public expenditures; i.e., $D_{x}>0, D_{T}>0$. The concavity assumption implies that public and private adaptation measures exhibit diminishing returns, so that $D_{x x}<0, D_{\boldsymbol{T} T}<0$. The marginal returns to expenditures on property, $D_{x}(x, z, \boldsymbol{T})$ and $D_{T}(x, z, \boldsymbol{T})$, vary with the severity of the hazard and, similar to Lewis and Nickerson (1989), we do not impose any restrictions on $D_{x z}$ and $D_{T z}$.

Using this setup, individuals are assumed to maximize the following utility function: ${ }^{8}$

$$
\max _{x} V=\max _{x} \int_{\underline{z}}^{\hat{z}} U(D(x, z, \boldsymbol{T})+W) d F(z)
$$

where the optimal level of private self-expenditure, $x^{*}$, from solving this utility maximization problem is a function of the exogenous level of wealth $(\mathrm{W})$, the severity of hazard defined by the distribution function $\mathrm{F}(\mathrm{z})$ and public adaptation expenditures, $\boldsymbol{T} .{ }^{9}$ Thus, the realized net property value accounting for the optimal private adaptation expenditure is defined as $D\left(x^{*}, z, \boldsymbol{T}\right)$. If we further normalize the initial value of property to equal unity, then the realized property losses from hazards can be defined as

$$
L\left(x^{*}, z, \boldsymbol{T}\right)=\int_{\underline{Z}}^{\hat{z}}\left(1-D\left(x^{*}, z, \boldsymbol{T}\right)\right) d F(z),
$$

This equation, given the optimal level of private self-expenditure, $x^{*}$, forms the basis for the following testable hypotheses:

\footnotetext{
${ }^{7}$ The function $D(x, z, \boldsymbol{T})$ captures the net property value after accounting for both private expenditures $(x)$, and public expenditures on disaster protection and assistance $(\boldsymbol{T})$ as well as impacts from the realization of random states of nature $(z)$.

${ }^{8} V(\cdot)$ and $U(\cdot)$ denote expected utility and utility function, respectively, assumed to be strictly concave in $x$.

${ }^{9}$ Individuals are assumed to view public adaptation expenditure as given. The optimal level of public protection and assistance is the level that minimizes cost, $\min _{T} \int_{\underline{z}}^{\hat{z}}(P \boldsymbol{T}-D(x, z, \boldsymbol{T})) d F(z)$.
} 


\section{Hypothesis I:}

The marginal effects of different types of public adaptation expenditures (ex-ante, expost) are ambiguous and depend on which of the two effects dominate: direct marginal effects of these measures on net property value $\left(D_{T}\right)$ or their effects on marginal net property value with respect to private self-insurance expenditures $\left(D_{x \boldsymbol{T}}\right){ }^{10}$

\section{Hypothesis II:}

Whether severe hazards imply higher or lower property losses depends on how marginal returns to private or public expenditures on net property value $\left(D_{x z}\right.$ and $\left.D_{\boldsymbol{T} z}\right)$ vary with the severity of the hazard. ${ }^{11}$

\section{Data}

To empirically test these hypotheses, we assembled data on 651 counties in the NorthAtlantic Basin of the United States. These counties are located relatively close to the coastline and have experienced property losses from hurricanes at least once during the period 1989$2009 .^{12}$

\subsection{Property Damages}

County-level property loss estimates associated with hurricane incidents are obtained from the Spatial Hazard Events and Losses Database for the United States (SHELDUS) (Hazards

\footnotetext{
${ }^{10}$ Private self-insurance expenditures and public disaster programs can be viewed as substitutes $\left(\frac{\partial x}{\partial T}<0\right)$ or complements $\left(\frac{\partial x}{\partial T}>0\right)$. In support of the former, the literature argues that public support and protection could crowd-out private adaptation (Lewis and Nickerson, 1989; Kunreuther, 2001; Raschky and Weck-Hannemann, 2007; Kousky, Michel-Kerjan and Raschky, 2013). For example, individuals who live in areas protected by a levee or a seawall may feel overly secure about the protectiveness of these structures and thus not purchase private insurance, or upgrade to windows and roofs that are wind resistance. By the same token, if households expect a third party will cover damages, they may not engage in exante self-protection. Certain adaptation measures such as warning systems and awareness programs could, on the contrary, entice private adaptive behavior. Personal experience with disasters can also motivate self-insurance behavior.

${ }^{11}$ Some adaptation measures are more effective in benign states of nature; for example, levees and dikes which are effective to the degree that their designed capacity withstands the hazard. Most of the levees in New Orleans were designed to handle up to a Category 3 hurricane impact. Their failure in a Category 5 event, along with institutional factors, has therefore resulted in even greater catastrophic loss. Other measures can be more effective in adverse states of nature. In an event of the blackout, for instance, auxiliary generators are very effective.

${ }^{12} 651$ sample counties are drawn from a sample of 864 counties that have experienced hurricane-induced property losses at least once since 1969 (Hazards \& Vulnerability Research Institute, 2010).
} 
\& Vulnerability Research Institute, 2010). SHELDUS county-level losses represent an equal distribution of total observed damage by specific hazard incidents across affected counties. Total losses by hurricane and flood incidents are based on the National Weather Service (NWS) Center Storm Dataset. NWS collects weather related storm events and corresponding losses on a monthly basis and rely on flood insurance companies, newspapers, and emergency managers. FEMA also keeps records on insured losses.

Gall et al. (2009) provide an extensive review of biases typically encountered in damage estimates across reporting agencies. Since we primarily focus on one type of hazard, some of these biases (e.g. hazard bias that arises when not all hazard types are reported) are not of particular relevance. Temporal bias arises when losses exhibit an upward trend over time due to population and wealth growth and improved accounting. This bias is typically found in most data sets; but is attenuated in our study because of the short time span, 1989-2009. Another potential bias is related to threshold bias (i.e., losses are reported only if they pass a certain threshold) since, prior to 1995 , SHELDUS would only report losses above $\$ 50,000$. After 1995 , however, all losses (even those that are insignificant) appear in the SHELDUS dataset since they also appear in NSW reports.

There are 353 unique incidents over which SHELDUS reports damages, corresponding to 63 named hurricanes during the sample period. An incident is defined as the estimated damages for a particular impacted state from a hurricane event. SHELDUS provides county-level estimates by dividing total state-level hurricane damages equally among impacted counties. The average number of counties impacted per hurricane incident is 17 with a maximum of 134 in 2005 (mainly related to the landfall of Hurricane Katrina). 
One of the limitations of SHELDUS is that it divides observed damage estimates for specific hazards equally across affected counties. To account for county-level variation in property losses, we developed weights using Emanuel's (2005) proposed wind speed and economic loss relationship, referred to as the Power Dissipation Index (PDI), defined as: $P D I=\int_{0}^{\tau} V_{\max }^{3} d t$, where $V_{\max }$ is the maximum sustained wind speed by county and $\tau$ is the period of hurricane persistence (season). Under the assumption that $P D I \approx$ Economic Damage, using the NOAA best hurricane track observations (NOAA, 2010) for every observed point on a hurricane track at 6-hourly intervals, we calculate the cube of wind speed for every county centroid and sum over the entire hurricane season for each individual county. ${ }^{13}$ We then calculate PDI as $\sum_{i=1}^{N} \int_{0}^{\tau} V_{\text {max }_{i}}^{3} d t$, where $i=\{1, \ldots, N\}$ and $N$ is the total number of affected counties SHELDUS uses to derive the average county-level damage estimates from individual incidents. ${ }^{14}$ Correspondingly, weights $\left(w_{i}\right)$ were generated using the simple share rule $w_{i}=\frac{\int_{0}^{\tau} V_{\max _{i}}^{3} d t}{\sum_{j=1}^{N} \int_{0}^{\tau} V_{\max _{j}}^{3} d t}$ which were further applied to county-level damage estimates recorded by SHELDUS to generate individual county-level variations. ${ }^{15,16}$ Figure 1 depicts county level wind speed adjusted damages constructed using the PDI described above.

\section{[Insert Figure 1 about here]}

The use of wind speed to determine damages is advantageous as it avoids potentially confounding socio-economic regressors with construction of damage measures. While avoiding

\footnotetext{
${ }^{13}$ Wind speeds were calculated using the Willoughby-Darling-Rahn (Willoughby, Darling and Rahn, 2006) parametric wind distribution model, which along with other wind related parameters is the function of the distance between the observed 6-hourly hurricane track and the county centroid.

${ }^{14}$ Storm surge associated with a hurricane may also be an important determinant of coastal property damages. However, given the high correlation between PDI and the storm surge index (0.75) shown in the literature (Grinsted et al., 2012), we believe PDI is a good proxy for storm surge, as storm surge indices are unavailable.

${ }^{15}$ In certain years and certain counties we observe no property damage either because there were no major hurricane hits or because the hurricane did not cause any property loss in that year and county. Including zeros for years and/or counties where no positive property losses were recorded is important so that we do not ignore the potentially successful prior adaptation projects implemented in those areas that may have led to the avoidance of damages. Additionally, the spending for some mitigation programs may be delayed several years following a hurricane disaster and including zeros for those years/counties ensures that we account for successive projects.

${ }^{16}$ As a robustness check, we also report results using only insurance payments associated with flooding as a lower bound on damages.
} 
potentially introducing structural endogeneity, it is important to examine the resulting predictions of damages using wind speed measures at an aggregate storm level to ascertain the appropriateness of this measure, which we examine in subsequent results discussions. ${ }^{17}$ Figure 2 shows the average sample PDI constructed using wind speeds for each county overlaid with the cumulative number of hurricane incidents during the sample period.

[Insert Figure 2 here]

Additionally, Figures 3-5 show average population density, total number of housing units and housing value in 2010. ${ }^{18}$ The concentration of per capita damages as shown in Figure 1 closely aligns with the concentration of both wealth as well as population densities.

\section{[Insert Figures 3-5 here]}

Our damage estimates show that per capita property loss is highly skewed to the rightwith a per capita mean of $\$ 138.51$ and median of zero for the full sample. The highest per capita property loss observed in the data is $\$ 101,855$ associated with hurricane Katrina in Plaquemines Parish. To smooth the data, we log transform per capita property losses using $\ln (\operatorname{loss}+1)$. To include counties with zero damages, we add a numerical offset prior to taking logs. This transformation ensures that we keep the year-county observations with zero values in the sample and we provide additional hurdle model estimates for robustness that account for zero damages without this patch. ${ }^{19}$ The summary statistics for all of the model variables are provided in Table 1.

\subsection{Additional Explanatory Variables:}

\footnotetext{
${ }^{17}$ We also explored alternative damage appropriation approaches including the use of storm level prediction including select sociodemographic controls. We find little evidence to suggest that these approaches are strictly preferred to our exogenous wind speed predictions. These results are available upon request.

${ }^{18}$ Housing value was calculated as a product of the median house value and number of housing units using Census 2010 housing estimates.

${ }^{19}$ We present a model in which we do not impose the log transformation and find comparable results. These are provided in Tables A.1 \& A.2 of the online appendix.
} 
Additional explanatory variables are grouped into four categories: (i) physical exposure, (ii) economic exposure, (iii) infrastructure vulnerability, and (iv) adaptation expenditures. Historical hurricane exposure is captured by the cumulative number of hurricane hits since the year 1853 and is lagged by one year. We account for the number of other types of disaster declarations (both natural and man-made) using the FEMA disaster declaration database (FEMA, 2010c), also lagged by one year, as well as the county's proximity to the coast (the dummy for coastal counties interacted with the total number of tropical storms) (NOAA, 2011).

Economic exposure is proxied by per capita income obtained from the U.S. Bureau of Economic Analysis (BEA, 2010) as well as by changes in population and business establishments from the County Business Patterns Database of the U.S. Census Bureau (U.S. Census Bureau, 2010a). The changes in population and business establishments are lagged by one year. Infrastructure vulnerability is captured by the per capita total number of houses built before 1940 and mobile homes from the U.S. Decennial Census (U.S. Census Bureau, 2010b). Mean per capita income in the data set is approximately 10.11 in log terms.

We control for the effective enforcement of building codes by including a dummy variable that identifies whether in a given year a county was classified as a Community Rating System (CRS) program Class 7 or lower. ${ }^{20,21}$ Approximately $2.3 \%$ of the counties in our sample were classified as a CRS Class 7 and lower, suggesting that only a small percentage of the sample counties have better enforcement of building codes.

\subsection{FEMA Expenditures:}

\footnotetext{
${ }^{20}$ The CRS Program is a voluntary program initiated by the National Flood Insurance Program (NFIP) as part of the National Flood Insurance Reform Act (NFIR) enacted in 1994. The basic premise of the CRS program is to recognize and reward communities for flood control programs, as well as to provide incentives for communities to implement stringent regulatory policies in exchange for discounts on flood insurance premiums. The credit points earned by a county determine its CRS class category, which is then used to determine the county's flood insurance premium discount (Brody et al., 2009).

${ }^{21}$ The BCEGS (Building Codes Effectiveness Grading System) was developed by the Insurance Services Office (ISO) to evaluate building code performance with an emphasis on mitigation from natural hazards. The BCEGS grading is from 10 to 1 , in descending order, where 10 indicates the worst performance of building code enforcement and 1 indicates exemplary commitment (ISO, 2010).
} 
Our primary variables of interest are public adaptation expenditures based on FEMA's Public Assistance (FEMA, 2010d) and Hazard Mitigation Grants Programs (FEMA, 2010e). Both programs were established under the Robert T. Stafford Disaster Relief and Emergency Assistance Act enacted in 1988. These programs offer grants that serve as a supplementary source of assistance to various levels of government (State, Tribal, and Local) after the state's governor has requested a major disaster or emergency declaration from the US President, and has provided sufficient evidence that the disaster is of such severity and magnitude that effective response is beyond the capabilities of affected states and local governments.

The projects implemented through FEMA's Public Assistance and Hazard Mitigation Grants Programs are highly heterogeneous and serve different purposes. Some programs have long-term mitigation objectives, whereas others are primarily disaster response activities and thus have short-term objectives. For example, FEMA's Public Assistance Program provides grant assistance for debris removal, emergency protective measures, and the repair, replacement, or restoration of disaster-damaged public property. Projects funded through the Hazard Mitigation Grants Program must provide a long-term solution to a problem; for example, the elevation of a home to reduce the risk of flood damage as opposed to buying sandbags and pumps in response to flooding.

We group FEMA spending into two categories: (1) FEMA ex-ante (mitigation and planning) and (2) FEMA ex-post (response and recovery) projects. Mitigation eligible projects include acquisition of hazard prone property and conservation of open space, retrofitting existing buildings and facilities, elevation of flood prone structures, vegetative management/soil stabilization, infrastructure protection measures, storm water management, minor structural flood control projects, and post-disaster code enforcement activities. Planning programs include 
federal grants to communities for hazard mitigation planning and hazard identification purposes. Under these types of programs, localities are obliged to develop a comprehensive mitigation strategy for reducing risks to life and property and improving already existing warning systems. ${ }^{22}$

FEMA ex-post includes immediate response and emergency grants defined as "measures taken before, during and after a disaster to eliminate/reduce an immediate threat to life, public health, or safety, or to eliminate/reduce an immediate threat of significant damage to improved public and private property through cost-effective measures" (FEMA, 2010a). Examples include temporary levees, boarding windows to reduce further damage, demolition and removal of public and private buildings and structures that pose an immediate threat to the safety of the general public, and restoration of access. It also includes funds allocated for clean-up activities such as debris removal, removal of certain building wreckage, woody debris, damaged/destroyed building contents, sand, mud, silt, gravel and other disaster-related wreckage. This category also covers restoration of access such as roads and bridges and utility lines to facilitate rapid return and recovery.

To differentiate the effects of the ex-post program from those of the ex-ante activities funded by FEMA, we define a FEMA ex-ante variable as a one year lag of rolling cumulative spending in long term mitigation programs. On the other hand, the FEMA ex-post adaptation variable is measured as a measure of rolling cumulative spending in ex-post programs per capita from any prior incident. Both variables are annualized, yielding coefficients that are interpreted as responses to annual average increases in spending on these two programs. Similar to the dependent variable, these federal disaster expenditures are also highly skewed to the right and we

\footnotetext{
${ }^{22}$ Warning systems are somewhat uniform across U.S. states. Counties receive grants for activities implemented under code "600.1: Warning Systems (as a Component of a Planned, Adopted, and Exercised Risk Reduction Plan)" of the HMGP and includes projects such as enhancements to existing warning systems, updating area maps with survey information, purchasing computer hardware and software to establish a database, and developing warning procedures to be implemented by the city.
} 
therefore use $\log$ transformations to smooth the data. The sample average of the annualized cumulative from prior incidents FEMA spending on ex-post program is 0.67 in logs and reaches a maximum of 13.89. The mean of annualized cumulative FEMA spending on ex-ante mitigation and planning projects is 0.24 in logs, with a maximum of 4.34 . Finally, we convert all dollar values to 2005 real prices using a GDP implicit price deflator.

[Insert Table 1 Here]

\section{Estimation and Identification Strategy}

To estimate the effectiveness of FEMA disaster mitigation and public assistance programs on per capita property losses, we employ a variety of limited dependent variable model specifications to overcome challenges presented by the large number of observations containing zero property losses as well as potential endogeneity concerns. In particular, we specify a baseline Tobit model as:

$$
\begin{gathered}
L_{i t}^{*}=X_{i t} \alpha+\left(F E M A_{i t-1}\right) \beta+\lambda_{t}+\mu_{i}+\varepsilon_{i, t} \\
L_{i t}=\max \left(0, L_{i t}^{*}\right)=\max \left(0, X_{i t} \alpha+\left(F E M A_{i t-1}\right) \beta+\lambda_{t}+\mu_{i}+\varepsilon_{i, t}\right) \\
\varepsilon_{i t} \mid x_{i t}, \mu_{i} \sim N\left(0, \sigma_{\varepsilon}^{2}\right), \quad t=1,2, \ldots, T
\end{gathered}
$$

where $L_{i t}$ represents per capita property loss for county $i$ at year $t$, and $X_{i t}$ consists of variables related to physical hazard exposure, economic exposure and infrastructure vulnerability described previously. The key variables of interest, public adaptation measures funded by FEMA $\left(F E M A_{i t-1}\right)$, are represented by cumulative $F E M A$, ex ante at-1 $_{i t-1}$ and $F E M A$, ex post cumulative ex-post adaptation from the prior incident. Lastly, $\lambda_{t}$ represents year fixed effects and $\mu_{i}$ captures unobserved heterogeneity. 
The inclusion of fixed effects in a limited dependent variable model poses the wellknown incidental parameters problem in maximum likelihood (Greene, 2003). As a result, the coefficients of the fixed effects Tobit model are likely imprecise resulting in inconsistent estimates of the slope coefficients. However, Rosenthal and Strange (2003) argue that bias in nonlinear models is eliminated as the number of observations per fixed effect becomes arbitrarily large, a condition we are likely to meet in our application.

An alternative specification to the fixed effects Tobit model is a more general random effects model, which allows $\mu_{i}$ and $X_{i}$ to be correlated (Wooldridge, 2003). This model assumes: $\mu_{i} \mid X_{i} \sim N\left(\varphi+\overline{x_{l}} \xi, \sigma_{a}^{2}\right)$ where $\sigma_{a}^{2}$ is the variance of $a_{i}$ in the equation $\mu_{i}=\varphi+\bar{x}_{l} \xi+a_{i}$. Under this specification the model defined in (3) becomes:

$$
\begin{gathered}
L_{i t}=\max \left(0, L_{i t}^{*}\right)=\max \left(0, X_{i t} \alpha+\left(F E M A_{i t-1}\right) \beta+\lambda_{t}+\overline{x_{l}} \xi+a_{i}+\varepsilon_{i, t}\right) \\
\varepsilon_{i t} \mid x_{i t}, a_{i} \sim N\left(0, \sigma_{\varepsilon}^{2}\right), \quad t=1,2, \ldots, T \\
a_{i} \mid x_{i t} \sim N\left(0, \sigma_{a}^{2}\right)
\end{gathered}
$$

where $\bar{x}_{\imath}$ represents an additional set of time constant explanatory variables appearing in each time period. Specifically, they represent panel averages of all time varying variables in the model. Adding $\bar{x}_{l}$ to a traditional random effects Tobit model solves the unobserved heterogeneity problem and results in consistent estimates for model parameters (Wooldridge, 2003; Chamberlain, 1984). We use bootstrapped standard errors allowing for clustering within congressional districts to account for potential heteroscedasticity and correlation of observations across time and counties within each congressional district given congressional oversight of the FEMA disaster spending and potential political influence. ${ }^{23}$

\footnotetext{
23

Alternatively, we consider clustering errors over a space which is larger than a county and include counties with similar hurricane exposure using Zandbergen (2009) hurricane exposure factors developed for U.S. counties using historic records of storm tracks since 1851. For each state (there are 22 states in the sample), we separate counties into different exposure bins: [0,20); [20;40); [40,60); and [60 \& above) and cluster counties over these spatial unit. These results are reported in Online Appendix Table A.7.
} 
To account for different marginal effects of FEMA spending along "extensive" vs. “intensive” margins, we also estimate Cragg’s double hurdle model (Cragg, 1971), which is an alternative to the corner solution Tobit model. The first tier of Cragg's model involves estimating the probability of damage conditional on FEMA investment in hazard mitigation and recovery and the second tier examines the effect of FEMA spending on realized positive losses. ${ }^{24}$ This effect is likely to be observed for the variety of structural and defensive projects captured in our ex-ante FEMA variable and helps assess if any of these defensive measures may, on the contrary, induce adverse impacts. The levee breach in New Orleans when Katrina hit the city in 2005 is a good illustration of such an adverse effect: a levee may reduce the probability of damage up until the hazard level reaches its designed capacity, but once the damage occurs, the effect of protection may no longer matter.

\subsection{Endogeneity of FEMA Policies}

One important aspect to note is that federal funds are likely tied to the level of damages inflicted by disasters. Although prior empirical evidence suggests political motivation in disaster declaration and the subsequent allocation of hazard mitigation and public assistance resources by FEMA, the size of federal projects are still largely determined by the amount of losses each community incurs after a major disaster declaration (Husted and Nickerson, 2014). As a result, one would expect unobservable factors that determine property losses $\left(\varepsilon_{i, t}\right)$ to be correlated with the underlying processes that generate the types of adaptation measures $\left(F E M A_{i t-1}\right)$ observed in our analysis.

24 Details on the empirical estimation of a two-tier Cragg model is provided in Burke (2009). 
A Correlated Random Effects model accounts for time constant unobservables, however, there may remain unobservables that vary over time that could be correlated with damages thus limiting our ability to effectively identify the true impacts of these measures. In particular, areas with the most protective/defensive structures and development regulation are those that have experienced the most damage historically. To control for time-varying correlation between $\varepsilon_{i, t}$ and FEMA adaptation policies, we employ a control function (CF) approach. The CF method entails estimating the following model:

$$
F E M A_{i t}=X_{i t} \beta+Z_{i t} \gamma+\lambda_{t}+\mu_{i}+\omega_{i t}
$$

where $Z_{i t}$ serves as an instrument and is excluded from the property loss model, and $X_{i t}$ includes the same socio-economic and physical exposure variables included in the property loss model. Computed generalized residuals $\left(\widehat{\omega}_{i, t}\right)$ from (5) are then included as a covariate in the property loss equation defined in equation (4) (Vella, 1993). The second stage involves estimating a property loss model of the following form:

$$
y_{i t}=X_{i t} \alpha+\left(F E M A_{i t-1}\right) \beta+\widehat{\omega}_{i t}^{F E M A} \gamma+\lambda_{t}+\bar{x}_{l} \xi+a_{i}+\varepsilon_{i, t}
$$

Significance of the coefficient $\gamma$ associated with $\widehat{\omega}_{i t}^{F E M A}$ indicates that endogeneity is present in the model. Inclusion of the generalized residual in the model controls for unobservables that if left unaccounted for would result in biased estimates (see Vella, 1993; Vella and Verbeek, 1999; Papke and Wooldridge, 2008). Consistency of control function estimators hinges crucially on the assumption of the model in (5) being correctly specified along with linearity in $E(\varepsilon \mid \omega)$ (Imbens and Wooldridge, 2007). Since FEMA adaptation variables also 
consist of many zeros and continuous positive values, the reduced form model in (5) is estimated as a Random Effects Tobit Model. ${ }^{25}$

In selecting an instrument, $Z_{i t}$ we must find a variable(s) that is correlated with the potentially endogenous variable, but uncorrelated with $\varepsilon_{i, t}$ in the property loss model. One possible instrument is a variable that captures the political factors influencing FEMA spending decisions. Presidential disaster declarations precede the approval of FEMA expenditures. Garrett and Sobel (2003) show that half of disaster spending is politically motivated. In fact, a political element appears at many levels. The Robert Stafford Disaster Assistance Act grants the president sole discretion to declare major disasters and emergencies without any pre-defined sets of criteria (Bea, 2005).

Procedurally, a Presidential disaster declaration is made after the governor of the affected state has provided sufficient evidence that the catastrophe is of such severity that it is beyond the capacity of state and local governments to cover. Although the Stafford Act stipulates several procedural actions the governor of the affected state should undertake, ${ }^{26}$ determining the level of "beyond the capacity of the state" is left solely to the governor. The sole discretion of the governor to request federal assistance, the quality and consistency of subsequent damage assessments of FEMA, and the discretionary power of the President to authorize spending based on these damage reports have raised questions about the transparency and efficacy of the disaster declaration process in the United States (McCarthy, 2011).

Reeves (2011) argues that Presidents exert this discretionary power to authorize disaster spending to specific constituencies for political benefit. His empirical findings show that, in

\footnotetext{
${ }^{25}$ Ricker-Gilbert, Jayne and Chirwa (2011) apply the CF method to a Tobit model to correct for endogeneity between fertilizer demand and fertilizer subsidy in their double-hurdle model. Similarly, Holden and Lunduka (2012) control for endogeneity between agricultural input use and fertilizer subsidy using a CF model by including generalized residuals from a reduced Tobit model into a CRE Probit model.

26 Examples include execution of the state-level emergency plan and an agreement to accept cost-share provisions and related informationsharing. Still, the process leaves broad discretion with the governor if he or she determines that a situation is "beyond the capabilities of the state."
} 
return, the electorate will "reward" the President for declared disasters and authorized spending. Furthermore, Garrett and Sobel (2003) also show that another avenue of political influence in allocating disaster funding across affected states may come through the power of the congressional oversight of FEMA spending. States with representatives in this oversight committee have been shown to receive disproportionately larger amounts of disaster aid. In fact, there is no mechanism (e.g. specific formula) ${ }^{27}$ in the Stafford Act that allows monitoring of the disaster aid allocation process other than FEMA's preliminary damage assessments, the validity and quality of which have been continually questioned.

In a recent study, Sobel et al. (2007) show that the reorganization of FEMA post-9/11 and, in particular, FEMA's merger with the Department of Homeland Security has reduced its influence over disaster spending across politically important states. However, the merger did not affect the president's favor for specific constituencies in politically strategic states.

Disaster declarations may also generate "political currency" that could be useful in presidential as well as state senate elections. "Swing voter" theory suggests that voters may be willing to compromise their loyalty for a favorite party in exchange for economic benefits (Dixit and Londregan, 1996; Linbeck and Weibull, 1987; Dahlberg and Johansson, 2002). Studies show that political parties appear to target relatively "moderate" groups of voters without strong party affiliations and who can be easily swayed. Similar to Deryugina and Kirwan (2015), to capture the extent of a county's "moderate" voter population, we use the percentage of individuals voting for the independent candidate during the most recent presidential election. Independent voters tend to care less about election outcomes, and thus represent a strategic target group during election campaigns (Mayer, 2007). Dave Leip's Atlas of U.S. Presidential Elections data for

\footnotetext{
27 The act explicitly prohibits usage of any arithmetic formula in allocating disaster assistance.
} 
county-level elections outcomes were used to create this variable. ${ }^{28}$ The average percentage of voters choosing an independent candidate in their county is approximately $5 \%$, with a maximum of 39\% in Sagadahoc County, ME during the 1996 presidential election.

To capture political biases resulting from congressional oversight of FEMA spending, we collected data on congressional committee members from the biennial editions of the Almanac of American Politics. We rely on Garrett and Sobel (2003) for a list of nine subcommittees, four in the House and five in the Senate that oversee FEMA operations. Under the Stafford Act, several subcommittees are directly responsible for controlling FEMA disaster spending (i.e. Stafford Subcommittees) and others oversee minor FEMA programs (e.g. earthquake safety, fire prevention and flood insurance). Table 2 lists the relevant committees and subcommittees within the House and Senate and Figure 6 depicts congressional districts for the sample counties.

[Insert Table $2 \&$ Figure 6 about here]

While the total number of members in each subcommittee does not vary substantially over time, the extent of state representation does change. Some states may have more than one legislator in each subcommittee, while others may not be represented at all. We created a dummy variable that equals one if the state is represented in at least one of the Stafford or Non-Stafford committees responsible for overseeing FEMA disaster and non-disaster related programs. Lastly, we created another instrument using state senate elections data which are held every two years. Using data obtained from Dave Leip's Atlas of U.S. Presidential Elections, we construct an indicator variable equaling one if the state senate majority is represented by the same party as the party of incumbent President.

\footnotetext{
28 Obtained from http://uselectionatlas.org/. There are six recent presidential election years relevant for the sample:1988, 1992, 1996, 2000, 2004 and 2008.
} 
Our final set of instruments include: (1) the percentage of voters choosing the independent party candidate in a presidential election, lagged one year prior to FEMA expenditure; (2) a dummy variable equal to 1 if the state is represented in at least one of the Stafford or non-Stafford Committees in the same year as the FEMA spending; and (3) a dummy variable equal to 1 if the county's political majority in the state's senate election is the same as the political party of the incumbent President. The updated specification of equation (5) using these instruments is

$$
\text { FEMA }_{i t}=X_{i t} \beta+\% \operatorname{Ind}_{i t-1} \gamma_{1}+\text { Committee }_{i t} \gamma_{2}+\text { SenPres }_{3}+\lambda_{t}+\mu_{i}+\omega_{i t}
$$

Ceteris paribus, the presence of the state senators in one of the FEMA oversight committees (Stafford or Non-Stafford), the higher the state's influence on FEMA spending decisions after the President has declared a disaster. We expect counties with a large number of independent voters to also influence a President's disaster declaration decision. Last, many important initiatives and public projects are passed through if the political majority of the state is in alliance with the President. We expect a similar effect to hold particularly for public mitigation programs since the spending on FEMA hazard mitigation programs are capped at $15 \%$ of FEMA's total budget for disaster related programs.

As indicated by the first stage model results presented in Table 3, FEMA ex-ante programs are higher in swing counties during Presidential elections, positively impacted by State representation in at least one of the Stafford or Non-Stafford oversight committees, and are higher if the county's political majority in the State senate election is the same as the political party of the incumbent President. On the other hand, FEMA disaster spending on ex-post recovery and clean-up is significantly higher if the disaster impacted state is represented in one 
of the Stafford or Non-Stafford committees in the house or senate overseeing various aspects of FEMA's operations.

[Insert Table 3 Here]

\section{Results}

In Table 4 we present results from the Correlated Random Effects Tobit model (column 1), which includes the means of all time varying explanatory variables to control for unobserved heterogeneity, but ignores potential endogeneity issues associated with the FEMA variables. Column 2 of Table 4 presents results from the Control Function Correlated Random Effects Tobit model which, in addition to accounting for unobserved heterogeneity, controls for potential endogeneity issues associated with the FEMA variables. This model includes generalized residuals from the first stage regression reported in Table 3 in which cumulative ex-ante and expost FEMA spending from prior event are regressed on all model variables and the political instruments.

The results from the correlated random effects Tobit model suggest that ex-ante FEMA programs have significantly negative effects on property losses; however, we find an insignificant negative coefficient associated with ex-post FEMA programs. After addressing potential endogeneity issues, we find in column (2) the coefficient associated with the ex-post FEMA variable becomes significant. The significant coefficients associated with the generalized residuals of the ex-post and ex-ante FEMA variables indicate that these variables are highly endogenous in the model. Moreover, positive signs associated with the generalized residuals indicate that unobserved factors that result in a higher level of ex-post and ex-ante FEMA investment also produce larger property losses; thus the bias is upward (Vella, 1993). Noticeably, not only the significance but the magnitude of the coefficient associated with the ex-post FEMA 
variable change after inclusion of the first stage residuals in the property loss model. While the sign remains consistent, the magnitude of the coefficient associated with the FEMA ex-ante adaptation also increases and almost doubles. Thus, given the evidence supporting potential endogeneity issues associated with the FEMA variables, we adopt the Control Function Correlated Random Effects model results as our main results.

\section{[Insert Table 4 Here]}

Results from the Control Function Correlated Random Effects model reveal that economic exposure is a primary driver of property losses. This is seen by the positive and significant coefficients associated with per capita income and business establishment change. These are consistent with previous studies examining the relationship between the size of the economy and disaster losses (Kellenberg and Mobarak, 2008; Schumacher and Strobl, 2011) and also support Pielke et al. (2008) who raise awareness of the potential threat associated with the growing concentration of population, property and wealth along coastlines. Consistent with the social vulnerability literature of natural disasters (Cutter, Boruff and Shirley, 2003), the results also suggest that more vulnerable infrastructure exacerbates damages; i.e., the coefficient associated with the vulnerable housing stock variable is positive and significant in the model.

We also find that geography and physical exposure are important contributors to property loss. The coefficient associated with the exposure variable (coastal communities) is statistically significant and positive. We did not find evidence that counties with prior hurricane exposure necessarily experience lower property losses reflecting mitigation measures already in place. The positive sign associated with cumulative historic hurricane hits suggests an opposite effect, however the effect is insignificant. A county where other types of disasters were declared one 
year prior incurs less property loss from a hurricane incident in the following year and this effect is significant at the $5 \%$ significance level.

Controlling for economic, physical, and infrastructure vulnerability, we isolate the effects of the two types of FEMA spending. Table 5 presents the conditional and unconditional marginal effects associated with the FEMA variables from the model specification presented in column 2 of Table 4. Since both the dependent variable and the FEMA variables of interest are in log terms, the marginal effects represent elasticities estimated at the sample mean for all of the explanatory variables. ${ }^{29}$

Results indicate that a one percent increase in per capita FEMA spending on public assistance and cumulative mitigation programs results in a less than one percent reduction in per capita property losses. The conditional mean elasticities associated with the cumulative ex-ante FEMA spending and ex-post spending from prior incident are approximately -0.21 and -0.12 , respectively (see column (1) of Table 5).

\section{[Insert Table 5 Here]}

In Table 6, we report the results in which we examine both the extensive and intensive impacts of FEMA spending. Our extensive measure captures potential changes to the probability of damage occurring while the intensive measure captures how severe damage is likely to be conditional on damage occurring. Column 1 of Table 6 reports the first tier results of the Cragg's log normal double hurdle model, which estimates a Probit model and captures the effects of FEMA programs along the extensive margin. Column 2 of Table 6 reports estimates corresponding to the effects along the intensive margin. As hypothesized, ex-ante FEMA

\footnotetext{
29 We acknowledge that the assumption of constant elasticity between FEMA programs and damages as is imposed by the log-log model specification is too restrictive. In reality, many public goods exhibit diminishing returns per additional dollar investment, suggesting that marginal benefits decrease as FEMA investment increases - an effect we observe in the semi-log model specification provided in Appendix Tables A.1 \& A.2.
} 
expenditure has significant loss mitigating effects on reducing the probability of losses. Along the intensive margin, we find that the effect of ex-ante FEMA expenditure is insignificant, while the ex-post FEMA variable is negative and highly significant. This suggests that recovery spending from prior incidents is an important contributor to reducing the severity of damages once they occur, possibly reflecting the role of recovery spending in repairing vulnerable infrastructure.

[Insert Table 6 about here]

\section{Robustness}

To examine the predictive power of our model as well as validate whether apportioning damages using wind speeds could introduce bias, we predicted per capita damages using the model results reported in column (2) of Table 4. We then aggregated these individual county level predicted damages to generate storm-level damage predictions and compared them with actual storm-level damages reported by SHELDUS. To examine the differences between predicted and actual damages, in Table 7 we report the $10^{\text {th }}, 25^{\text {th }}, 50^{\text {th }}, 75^{\text {th }}$ and $90^{\text {th }}$ percentiles of predicted and actual damages along with sample means. Both the median and the mean of the predicted and actual damage measures are very close, suggesting that mean estimated marginal elasticities of FEMA variables do not appear to be significantly biased. At low damage levels we over-predict damages while our model under-predicts high damage events.

[Insert Table 7 about here]

For robustness, we also estimated the model in equation (5) using the National Flood Insurance Program (NFIP) flood insurance payments by county in lieu of wind speed approximated hurricane-induced damages. Data on flood insurance payments was obtained 
through a Freedom of Information Act (FOIA) request to FEMA. As suggested by the coefficients and marginal effects reported in Appendix Tables A.3 and A.4, both the ex-ante and ex-post FEMA expenditure variables are associated with negative coefficients; however only exante FEMA programs are marginally significant at the $10 \%$ significance level. The magnitudes of both coefficients are smaller relative to those of our main model results; however the relative marginal effects are again similar across program categories. The finding of lower magnitudes is not surprising given that flood insurance penetration is low across U.S. counties and insurance is only mandated by mortgage companies for homes located in FEMA designated flood plains. As such, NFIP payments represent a lower bound on damages as they do not capture uninsured losses as well as wind-related damages which are sizeable for hurricane struck communities. ${ }^{30}$

As a robustness check we also estimated the model where a log transformation was not imposed on the dependent variable. These results were consistent with the main model results both in terms of the sign, significance as well as relative magnitudes of the coefficients. (See Appendix Table A.1 \& A.2). In addition, Poisson model results reported in Appendix Table A.5 yielded consistent and comparable estimates. ${ }^{31}$

The two categories of FEMA spending may interact in some way or lead to a change in behavior or beliefs (i.e., a large strike could increase both ex-post recovery spending and subsequent ex-ante grants). To explore differences in effects between ex-post and ex-ante FEMA program spending (since the most recent incident may affect subsequent damages), additionally we estimated the model where FEMA ex-ante program spending is defined as spending since the

\footnotetext{
${ }^{30}$ We also performed a placebo exercise randomly reassigning wind weights (PDI) to the dependent variable across sample counties, an approach adopted by Hsiang and Jina (2014). These placebo results indicate that the model is unlikely to produce biased results and most importantly, these results are unlikely to happen by chance. Placebo results are available upon request.

31 Apportioning damages using wind speeds, while appealing because exogeneity is preserved, does not account for capital- and populationexposure which also drive significant variation in damages. To provide additional robustness for our results, we in addition estimated a stormlevel model, in which total storm-specific damages are regressed on total wind exposure, population, vulnerable housing stock and wealth. We then used estimated coefficients from this model to predict damages at the county-level and re-estimated the county-level model presented by equation (6). The results were comparable both in terms of coefficient significance as well as magnitudes and are available upon request.
} 
prior incident. Our results suggest that spending on ex-ante projects in response to an earlier incident has a negative but statistically insignificant effect on subsequent damages (see column (1) of Appendix Table A.8). This is not surprising given that many ex-ante projects may take several years until they are complete and fully effective, while recovery and response projects (e.g., debris removal, facilitating access and restoration of roads and public utilities) have a more immediate effect. To validate this point, we also estimated the model where two types of FEMA ex-ante spending are included: (i) ex-ante spending in response to the most recent incident; and (ii) cumulative ex-ante excluding spending in response to the most recent incident. These results are reported in column (2) of Table A.8.

\section{Discussion}

Similar to previous studies, our study suggests that economic exposure and socioeconomic vulnerability are primary drivers of property losses. Additionally more vulnerable infrastructure exacerbates damages. Our results suggest that, at the margin, return in terms of property loss reduction is higher for ex-ante long-term mitigation investments relative to ex-post spending on recovery and clean-up projects. However, findings from the double hurdle model also suggest that ex-ante project spending reduces the probability of damage occurrence, while ex-post project spending results in significant loss mitigating effects at the intensive margin.

Using estimated elasticities across project categories combined with historical spending on ex-ante and ex-post programs per capita, we estimate that for every dollar spent on FEMA exante projects per capita generated approximately $\$ 1.15$ in reduced property losses while ex-post program spending per capita generated approximately $\$ 0.53$ in reduced property losses. Large 
FEMA spending on Public Assistance and Hazard Mitigation programs occurred in response to Super storm Sandy that made a landfall in October of 2012. President Obama declared disasters and emergencies in 13 states and 366 counties impacted by the storm. Annual per capita spending on hazard mitigation programs after Sandy was approximately $\$ 8.43$ (2005 US\$) while annual per capita spending on public assistance programs among impacted communities was $\$ 51.96$, making up $14 \%$ and $86 \%$ of the total FEMA spending on public programs, respectively (FEMA, 2016a; 2016b). ${ }^{32}$

Given our elasticity estimates, reduced property losses from these FEMA expenditures totaled $\$ 37.5$ per capita. Of this, $\$ 9.7$ per capita can be attributed to HMGP (ex-ante) while \$27.8 can be attributed to PA (ex-post) programs. Assuming constant returns on investment, this suggests that if spending on HMGP was doubled (i.e. if approximately 16\% of PA funds were allocated to HMGP), the additional reduction in damage losses would have reached $\$ 42.7$ per capita. Thus such a redistribution of project spending would mitigate an additional \$348 million dollars in aggregate property losses in Sandy impacted states.

Given differences in the estimated marginal returns between ex-ante mitigation and expost recovery programs, identifying potential mechanisms for these differences could offer valuable insights to questions related to the optimal adaptation to climate shocks. As posited in Hypothesis I, the marginal effect of the two types of FEMA spending is the joint effect of the direct marginal effect of these measures on net property values, assumed to be negative, and their effect on marginal net property value with respect to private self-insurance expenditures. The sign of the latter effect is positive if private and public efforts are substitutes and negative if they are complements. Estimating the negative marginal effects of these FEMA programs and not

\footnotetext{
32 Individual assistance and housing assistance is another FEMA disaster relief program, which is not accounted for in this study.
} 
directly observing private adaptation behavior, we can only say that either (a) private adaptation complements public efforts or (b) if they are substitutes then the direct marginal effect of the FEMA programs dominate the effect of limited private adaptive behavior due to moral hazard or perverse incentives these programs may generate.

FEMA ex-ante projects target long-term mitigation projects and planning, hazard identification as well as warning systems. Some of the funded programs such as storm water management, improvement in levee structures may be viewed as substitutes to private adaptation if they perversely affect private individuals' adaptive behavior. However, at the margin, the direct marginal effects $\left(D_{T}\right)$ of these programs appear to dominate. Other ex-ante programs, often funded under HMGP, include the demolition of private and public structures in hazardprone areas and the preservation of open space, which naturally imply less exposure to subsequent hazards. Hazard identification and warning systems are other important ex-ante programs and their loss-reducing features potentially imply that they may incentivize and further complement private individuals' self-protection/self-insurance expenditure (e.g. installing gutters, upgrading roofs and windows).

Similarly, we are not able to directly identify whether ex-post programs are complements or substitutes for private adaptation; however, by examining the features of funded projects we can discuss the likely implications of underlying private adaptation effects on damages. For instance, debris and wreckage clean-up projects funded under Public Assistance programs could crowd-out private actions targeting these activities. However, these program are still effective because they reduce potentially damaging trees, structures and lead to lower damages from subsequent events. These clean-up activities also clear clogged sewage systems, ditches and other structures from debris and thus guarantee their effective functionality during subsequent 
events. On the other hand, projects that facilitate restoration of utilities, lifelines, public buildings and access to roads provide opportunities for rapid recovery and likely facilitate effective private adaptation behavior and recovery; i.e. these programs can be viewed as complements to private hazard mitigation. ${ }^{33}$

Observable property losses represent only a small component of the full impacts from a disaster. Behavioral changes as a result of destruction may result in reduced income and changes in consumption/investment behavior (e.g. disinvestment in human capital and health) in the long term (Antilla-Hughes and Hsiang, 2013). Permanent relocation and outmigration may further induce persistent socio-economic aftereffects in disaster impacted regions (Hornbeck, 2012; Vigdor, 2008). In addition to disaster-specific programs, other outlays such as non-disaster related government transfers (e.g. social safety programs) are important and can buffer the adverse impacts of a disaster (Deryugina, 2013).

While only focusing on a specific component of disasters, our results are important and have implications for designing optimal adaptation strategies across communities and are also informative for disaster response and recovery efforts involving international stakeholders. For some communities it may be socially optimal to not invest in costly mitigation projects beforehand and instead wait to respond until after a hazard event has occurred. This strategy seems particularly suitable for places where the cost of ex-ante mitigation is high relative to the benefits of avoided losses associated with catastrophic events, and in particular if these events are relatively rare. ${ }^{34}$ Importantly, our findings are consistent with the priorities set forth for

\footnotetext{
${ }^{33}$ Identifying specific types of spending within the two FEMA categories that drive the overall effects is interesting for policy and offers some insights about the effectiveness of more granular spending categories, listed in online appendix Table A.8. As a robustness check, a simple Monte Carlo type of analysis was conducted where we included a single ex-ante and/or ex-post measure in each equation to examine point estimates separately. FEMA ex-post projects were grouped into four different categories and FEMA ex-ante programs were separated into 6 different sets of categories. Estimated coefficients for individual types were consistently negative and significant for the most part, implying the stability of the results and this categorization. These results are presented in Online Appendix Tables A.9-A.12.

34 Hsiang and Jina (2014) provide empirical evidence that shows countries not well-adapted to cyclones sustain higher marginal income losses, but also experience fewer storms.
} 
communities and countries worldwide over the $2015-2030$ period in the Sendai Framework for Disaster Risk Reduction (UNISDR, 2015). Among the four major priorities, three pertain to investing in disaster risk reduction, understanding risk and strengthening disaster risk governance. Notably, the remaining priority emphasizes the enhancement of disaster preparedness for effective response, using the disaster as an "opportunity" to rebuild better in the recovery and rehabilitation stage. Our findings underscore the importance of effective recovery in reducing damages from recurring hurricanes.

Current FEMA disaster policy requires that no more than $15 \%$ of total FEMA spending can be allocated to the Hazard Mitigation Grants Program (FEMA, 2013). ${ }^{35}$ On the contrary, disaster spending in the aftermath of a hurricane is rising which is not surprising given that recovery spending is directly proportional to disaster inflicted damages. While FEMA has undergone significant reorganization and operational changes since the enactment of the Stafford Act and multiple accounts of failed and ineffective performances during past emergencies and disasters (Schneider, 1998; 2008), recovery and relief spending remains a dominant response strategy of the agency. This strategy, while effective, is and will continue to be socially very costly under future climate change (Kousky, 2014a). Moreover, public perception of government and post-disaster expectation for support is often higher and surpasses the capability of the government to provide timely recovery resources as disastrous events are random and unpredictable in magnitude. This, in turn, results in a general dissatisfaction and frustration with government relief efforts (Schneider, 1998; 2008). While post-disaster assistance is extremely effective and can foster more rapid recovery, there is a potential gain from shifting disaster

\footnotetext{
35 We remind readers that the HMGP does not cover federal levee investment programs, which are typically the responsibility of the U.S. Army Corps of Engineers.
} 
policy priorities towards ex-ante hazard mitigation that could lead to long-term sustainability and enhanced resilience of communities to future hazards.

\section{Conclusions}

In this paper we estimate a control function Tobit model controlling for endogeneity to measure the effects of public adaptation measures on mitigating hurricane induced property losses among the North-Atlantic basin counties over the period 1989-2009. Controlling for physical and economic exposure, as well as infrastructure vulnerability of exposed counties, we

directly test the relative effectiveness of the projects funded through the FEMA Public Assistance and Hazard Mitigation Programs.

We estimate the conditional elasticity for mitigation planning, warning and hazard awareness as well as long term mitigation programs (e.g. improvements in structures) to be 0.21 , while that for clean-up and immediate response programs of FEMA to be 0.12 . We also find that FEMA ex-ante programs reduce the probability of damages, while FEMA ex-post programs are effective in terms of reducing realized property losses.

Despite the higher return from FEMA ex-ante project spending relative to spending on recovery and response activities, historically spending on recovery and assistance in the aftermath of a hurricane has been the dominant strategy in the United States. As mandated, no more than $15 \%$ of FEMA total disaster spending can be allocated to Hazard Mitigation Grants programs, which provide long term solutions to hazards, while there is almost no limit to spending on ex-post public assistance programs. Projections showing an increase in the frequency of North-Atlantic hurricanes and associated economic losses imply that a disaster strategy focused on ex-post recovery will most likely be very costly. As suggested by our study, redirecting FEMA spending to hazard awareness and warning systems as well as long term 
mitigation programs will yield larger returns on investment. However, there is a significant benefit in effective and timely response - a strategy that could be adopted by counties experiencing less-frequent hurricane exposures.

Our results provide important evidence for policy makers and researchers who are considering alternative adaptation strategies in response to climate change, sea-level rise and other natural calamities. Long-term mitigation solution to hazards as well as information and hazard awareness plays an important role in risk-perception and, if effectively communicated, will induce private agents to adapt on their own. Furthermore, of equal importance is the level of disaster preparedness by communities to facilitate rapid response and clean-up efforts. We do not find any evidence that protective and defensive measures actually amplify disaster shocks and fail to protect; however their effectiveness disappears once the damage is realized. Lastly, further research is needed to assess the potential existence of moral hazard and, in particular, to assess the relationship between structural projects and private agents' behavioral responses. 


\section{References}

Anttila-Hughes, J. K., \& Hsiang, S. M. (2013). Destruction, disinvestment, and death: Economic and human losses following environmental disaster. Available at SSRN 2220501.

Barone, M. and Ujifusa, G. (1988). The Almanac of American Politics 1988. National Journal. Washington, D.C.

Barone, M. \& Ujifusa, G. (1990). The Almanac of American Politics 1990. National Journal. Washington, D.C.

Barone, M. \& Ujifusa, G. (1992). The Almanac of American Politics 1990. National Journal. Washington, D.C.

Barone, M. \& Ujifusa, G. (1994). The Almanac of American Politics 1990. National Journal. Washington, D.C.

Barone, M., Ujifusa, G. \& Cohen, R.E. (1996). The Almanac of American Politics 1996. National Journal. Washington, D.C.

Barone, M., Ujifusa, G. \& Cohen, R.E. (1998). The Almanac of American Politics 1998. National Journal. Washington, D.C.

Barone, M., Ujifusa, G., Cohen, R.E. \& Cook Jr., C.E. (2000). The Almanac of American Politics 2000. National Journal. Washington, D.C.

Barone, M., Cohen, R.E. \& Cook Jr., C.E. (2002). The Almanac of American Politics 2002. National Journal. Washington, D.C.

Barone, M., \& Cohen, R.E. (2004). The Almanac of American Politics 2004. National Journal Group. Washington, D.C.

Barone, M., \& Cohen, R.E. (2006). The Almanac of American Politics 2006. National Journal Group. Washington, D.C.

Barone, M., \& Cohen, R.E. (2008). The Almanac of American Politics 2008. National Journal Group. Washington, D.C.

Bea, K. 2005. Federal Stafford Act Disaster Assistance: Presidential Declarations, Elihible Activities and Funding. CRS Report for Congress. Congressional Research Service. The Library of Congress. RL 33053.

BEA. 2010. Bureau of Economic Analysis, US Department of Commerce.[Online Database]. Retrieved 30 August, 2010 from http://www.bea.gov/regional/index.htm 
Brody, S. D., Zahran, S., Maghelal, P., Grover, H., \& Highfield, W. E. (2007). The rising costs of floods: Examining the impact of planning and development decisions on property damage in Florida. Journal of the American Planning Association, 73(3), 330-345.

Brody, S. D., Zahran, S., Highfield, W. E., Bernhardt, S. P., \& Vedlitz, A. (2009). Policy learning for flood mitigation: a longitudinal assessment of the community rating system in Florida. Risk analysis, 29(6), 912-929.

Burby, R. J. (2005). Have state comprehensive planning mandates reduced insured losses from natural disasters?. Natural hazards review, 6(2), 67-81.

Burke, W. J. (2009). Fitting and interpreting Cragg's tobit alternative using Stata. Stata Journal, 9(4), 584.

Burton, I. (1997). Vulnerability and adaptive response in the context of climate and climate change. Climatic Change, 36(1-2), 185-196.

Cavallo, E., \& Noy, I. (2011). Natural disasters and the economy-a survey. International Review of Environmental and Resource Economics, 5(1), 63-102.

Chamberlain, G. (1984). Panel data. Z. Griliches, M.D. Intriligator (Eds.), Handbook of econometrics, Vol. 2Elsevier, Amsterdam (1984), pp. 1247-1313.

Cragg, J. G. (1971). Some statistical models for limited dependent variables with application to the demand for durable goods. Econometrica: Journal of the Econometric Society, 829844.

Cutter, S. L., Boruff, B. J., \& Shirley, W. L. (2003). Social vulnerability to environmental hazards*. Social science quarterly, 84(2), 242-261.

Dahlberg, M., \& Johansson, E. (2002). On the vote-purchasing behavior of incumbent governments. American Political Science Review, 96(01), 27-40.

Davidson, R. A., \& Lambert, K. B. (2001). Comparing the hurricane disaster risk of US coastal counties. Natural Hazards Review, 2(3), 132-142.

Deryugina, T. (2011). The role of transfer payments in mitigating shocks: Evidence from the impact of hurricanes. Urbana-Champaign, IL: University of Illinois.

Deryugina, T., \& Kirwan, B. (2015). Does The Samaritan's Dilemma Matter? Evidence From US Agriculture. Working Paper.

Dixit, A., \& Londregan, J. (1996). The determinants of success of special interests in redistributive politics. Journal of politics, 58, 1132-1155.

Ehrlich, I., \& Becker, G. S. (1972). Market insurance, self-insurance, and self-protection. The Journal of Political Economy, 623-648. 
Emanuel, K. (2005). Increasing destructiveness of tropical cyclones over the past 30 years. Nature, 436(7051), 686-688.

Emanuel, K. A. (2013). Downscaling CMIP5 climate models shows increased tropical cyclone activity over the 21st century. Proceedings of the National Academy of Sciences, 110(30), 12219-12224.

FEMA. 2010a. Federal Emergency Management Agency. Public Assistance: Local, State, Tribal and Non-Profit. Accessed 30 September, 2010 at http://www.fema.gov/public-assistancelocal-state-tribal-and-non-profit

FEMA. 2010b. Federal Emergency Management Agency. Hazard Mitigation Grant Program. Accessed 30 September, 2010 at http://www.fema.gov/hazard-mitigation-grant-program

FEMA. 2010c. Federal Emergency Management Agency Disaster Declaration Summary [Online Database]. Retrieved 30 August, 2010 from http://www.fema.gov/library/viewRecord.do?id=6292

FEMA. 2010d. Federal Emergency Management Agency. Public Assistance Funded Projects Summary - Open Government Initiative. Retrieved 30 August, 2010 from http://www.fema.gov/library/viewRecord.do?id=6299

FEMA. 2010e. Federal Emergency Management Agency. FEMA Hazard Mitigation Program Summary - Open Government Dataset. Retrieved 30 August, 2010 from http://www.fema.gov/library/viewRecord.do?fromSearch=fromsearch\&id=6293

FEMA. 2013. Guidelines on HMGP. Available at http://www.fema.gov/media-librarydata/20130726-1717-25045-6338/55_hazard_mitigation_grant_program_ceiling.pdf. Accessed on December, 2013.

FEMA. 2016a. Disaster Relief Fund: Monthly Report Through January 1, 2014. Fiscal Year 2014 Report to Congress. January 6, 2014. Online Report available at http://www.fema.gov/media-library/assets/documents/31789. Accessed on June, 2016.

FEMA. 2016b. Disaster Relief Fund. January 5, 2015. Online Report available at http://www.fema.gov/media-library/assets/documents/31789. Accessed on June, 2016.

Gall, M., Borden, K. A., \& Cutter, S. L. (2009). When do losses count? Six fallacies of natural hazards loss data. Bulletin of the American Meteorological Society, 90(6), 799-809.

Garrett, T. A., \& Sobel, R. S. (2003). The political economy of FEMA disaster payments. Economic Inquiry, 41(3), 496-509.

Greene, W. H. (2003). Econometric Analysis. Upper Saddle River, NJ: Prentice Hall.

Grinsted, A., Moore, J. C., \& Jevrejeva, S. (2012). Homogeneous record of Atlantic hurricane surge threat since 1923. Proceedings of the National Academy of Sciences, 109(48), 19601-19605. 
Hazards \& Vulnerability Research Institute. (2010). The Spatial Hazard Events and Losses Database for the United States, Version 10.0 [Online Database]. Columbia, SC: University of South Carolina. Retrieved 30 August, 2010 from http://www.sheldus.org

Holden, S., \& Lunduka, R. (2012). Do fertilizer subsidies crowd out organic manures? The case of Malawi. Agricultural Economics, 43(3), 303-314.

Hornbeck, R. (2012). The Enduring Impact of the American Dust Bowl: Short- and Long-Run Adjustments to Environmental Catastrophe. American Economic Review, 102(4), 14772507.

Hsiang, S. M., \& Jina, A. S. (2014). The causal effect of environmental catastrophe on long-run economic growth: evidence from 6,700 cyclones (No. w20352). National Bureau of Economic Research.

Hsiang, S. M., \& Narita, D. (2012). Adaptation to cyclone risk: Evidence from the global crosssection. Climate Change Economics, 3(02), 1250011.

Husted, T., \& Nickerson, D. (2014). Political Economy of Presidential Disaster Declarations and Federal Disaster Assistance. Public Finance Review, 42(1), 35-57.

Imbens, G., \& Wooldridge, J. M. (2007). What's new in econometrics?. NBER.

ISO. 2010. Insurance Services Office. ISO's Building Code Effectiveness Grading Schedule (BCEGS) Update Project. Accessed 30 September, 2010 at http://www.isomitigation.com/building-code-regulation.html

Kahn, M. E. (2005). The death toll from natural disasters: the role of income, geography, and institutions. Review of Economics and Statistics, 87(2), 271-284.

Kellenberg, D. K., \& Mobarak, A. M. (2008). Does rising income increase or decrease damage risk from natural disasters?. Journal of Urban Economics, 63(3), 788-802.

Knutson, T. R., Sirutis, J. J., Vecchi, G. A., Garner, S., Zhao, M., Kim, H. S., \& Villarini, G. (2013). Dynamical Downscaling Projections of Twenty-First-Century Atlantic Hurricane Activity: CMIP3 and CMIP5 Model-Based Scenarios. Journal of Climate, 26(17).

Kousky, C. (2014). Informing climate adaptation: A review of the economic costs of natural disasters. Energy Economics, 46, 576-592.

Kousky, C. (2014a). Managing shoreline retreat: a US perspective. Climatic Change, 1-12.

Kousky, C., Luttmer, E. F., \& Zeckhauser, R. J. (2006). Private investment and government protection. Journal of Risk and Uncertainty, 33(1-2), 73-100.

Kousky, C., \& Olmstead, S. M. (2010). Induced development in risky locations: fire suppression and land use in the American West. Working paper. Washington, DC: Resources for the Future. 
Kousky, C., E.O. Michel-Kerjan, and P.A. Raschky. (2013). Does Federal Disaster Assistance Crowd Out Private Demand for Insurance? Risk Management and Decision Processes Center. The Wharton School, University of Pennsylvania. Working Paper \#2013-10.

Kunreuther, H. (2001). Mitigation and financial risk management for natural hazards. Geneva Papers on Risk and Insurance. Issues and Practice, 277-296.

Lewis, T., \& Nickerson, D. (1989). Self-insurance against natural disasters. Journal of Environmental Economics and Management, 16(3), 209-223.

Lindbeck, A., \& Weibull, J. W. (1987). Balanced-budget redistribution as the outcome of political competition. Public choice, 52(3), 273-297.

Mayer, W. G. (2007). The swing voter in American presidential elections. American Politics Research, 35(3), 358-388.

McCarthy, F. X. (2011). FEMA Disaster housing: from sheltering to permanent housing. DIANE Publishing.

Mileti D.S. (1999). Disasters by Design. Joseph Henry Press. Washington D.C.

NOAA. 1999. National Oceanic and Atmospheric Administration, US department of Commerce. Hurricane Basics, May 1999. www.noaa.gov, www.nhc.noaa.gov.

NOAA. 2010. National Weather Service. National Hurricane Center. [Online Database]. Retrieved 30 August, from http://www.nhc.noaa.gov/data/

NOAA. 2011. NOAA's List of Coastal Counties for the Bureau of the Census Statistical Abstract Series. Available from http://www.census.gov/geo/landview/lv6help/coastal_cty.pdf

Nordhaus, W. D. (2010). The economics of hurricanes and implications of global warming. Climate Change Economics, 1(01), 1-20.

Papke, L. E., \& Wooldridge, J. M. (2008). Panel data methods for fractional response variables with an application to test pass rates. Journal of Econometrics, 145(1), 121-133.

Pielke Jr, R. A., Gratz, J., Landsea, C. W., Collins, D., Saunders, M. A., \& Musulin, R. (2008). Normalized hurricane damage in the United States: 1900-2005. Natural Hazards Review, 9(1), 29-42.

Pielke Jr, R. A., \& Landsea, C. W. (1998). Normalized Hurricane Damages in the United States: 1925--95. Weather \& Forecasting, 13(3).

Quiggin, J. (1992). Risk, self-protection and ex ante economic value-some positive results. Journal of Environmental Economics and Management, 23(1), 40-53.

Raschky, P. A., \& Weck-Hannemann, H. (2007). Charity hazard-A real hazard to natural disaster insurance?. Environmental Hazards, 7(4), 321-329. 
Reeves, A. (2011). Political Disaster: Unilateral Powers, Electoral Incentives, and Presidential Disaster Declarations 1. The Journal of Politics, 73(4), 1142-1151.

Ricker-Gilbert, J., Jayne, T. S., \& Chirwa, E. (2011). Subsidies and crowding out: A doublehurdle model of fertilizer demand in Malawi. American Journal of Agricultural Economics, 93(1), 26-42.

Rosenthal, S. S., \& Strange, W. C. (2003). Geography, industrial organization, and agglomeration. Review of Economics and Statistics, 85(2), 377-393.

Sadowski, N. C., \& Sutter, D. (2005). Hurricane fatalities and hurricane damages: are safer hurricanes more damaging?. Southern Economic Journal, 422-432.

Sadowski, N. C., \& Sutter, D. (2008). Mitigation motivated by past experience: Prior hurricanes and damages. Ocean \& Coastal Management, 51(4), 303-313.

Schneider, S. K. (1998). Reinventing public administration: A case study of the Federal Emergency Management Agency. Public Administration Quarterly, 35-57.

Schneider, S. (2008). Who's to Blame?(Mis) perceptions of the Intergovernmental Response to Disasters. Publius: The Journal of Federalism, 38(4), 715-738.

Schumacher, I., \& Strobl, E. (2011). Economic development and losses due to natural disasters: The role of hazard exposure. Ecological Economics, 72, 97-105.

Sheets B., and J. Williams. (2001). Hurricane Watch: Forecasting Deadliest Storms on Earth. Vintage Books; 1st edition.

Shogren, J. F., \& Crocker, T. D. (1991). Risk, self-protection, and ex ante economic value. Journal of Environmental Economics and Management, 20(1), 1-15.

Silbert, M. E., \& Useche, P. (2011). Small island economic vulnerability to natural disasters (Doctoral dissertation, University of Florida).

Sobel, R. S., Coyne, C. J., \& Leeson, P. T. (2007). The political economy of FEMA: did reorganization matter?. Mercatus Center, George Mason University.

Strobl, E. (2011). The economic growth impact of hurricanes: evidence from US coastal counties. Review of Economics and Statistics, 93(2), 575-589.

Toya, H., \& Skidmore, M. (2007). Economic development and the impacts of natural disasters. Economics Letters, 94(1), 20-25.

UNISDR. 2015. Sendai Framework for Disaster Risk Reduction 2015-2030. United Nations Publication. The United Nations Office for Disaster Risk Reduction.

U.S. Census Bureau. 2010a. County Business Patterns (CBP). Retrieved 30 August, 2010 from http://www.census.gov/econ/cbp/ 
U.S. Census Bureau. 2010b. Selected Historical Decennial Census Population and Housing Counts. Retrieved 30 August, 2010 from http://www.census.gov/population/www/censusdata/hiscendata.html

U.S. Census Bureau. 2015. National $113^{\text {th }}$ Congressional District Map. Retrieved 20 April, 2015 from https://www.census.gov/geo/maps-data/maps/reference-cd113.html

U.S. Census Bureau. 2015a. 2010 Land area. The TIGER/Geographic Identification Code Scheme (TIGER/GICS). Retrieved January, 2015 from http://www.census.gov/geo/www/tiger/index.html.

Vella, F. (1993). A simple estimator for simultaneous models with censored endogenous regressors. International Economic Review, 441-457.

Vella, F., \& Verbeek, M. (1999). Two-step estimation of panel data models with censored endogenous variables and selection bias. Journal of Econometrics, 90(2), 239-263.

Vigdor, J. (2008). The economic aftermath of Hurricane Katrina. The Journal of Economic Perspectives, 22(4), 135-154.

Villarini, G., \& Vecchi, G. A. (2013). Projected Increases in North Atlantic Tropical Cyclone Intensity from CMIP5 Models. Journal of Climate, 26(10).

Ward, P., \& Shively, G. (2011). Disaster risk, social vulnerability and economic development. Unpublished Manuscript. Purdue University.

Webster, P. J., Holland, G. J., Curry, J. A., \& Chang, H. R. (2005). Changes in tropical cyclone number, duration, and intensity in a warming environment. Science, 309(5742), 18441846.

Willoughby, H. E., Darling, R. W. R., \& Rahn, M. E. (2006). Parametric representation of the primary hurricane vortex. Part II: A new family of sectionally continuous profiles. Monthly weather review, 134(4).

Wooldridge, J. M. (2003). Econometric analysis of cross section and panel data. MIT press. $2^{\text {nd }}$ Edition.

Zandbergen, P. A. (2009). Exposure of US counties to Atlantic tropical storms and hurricanes, 1851-2003. Natural Hazards, 48(1), 83-99. 


\section{Figures}

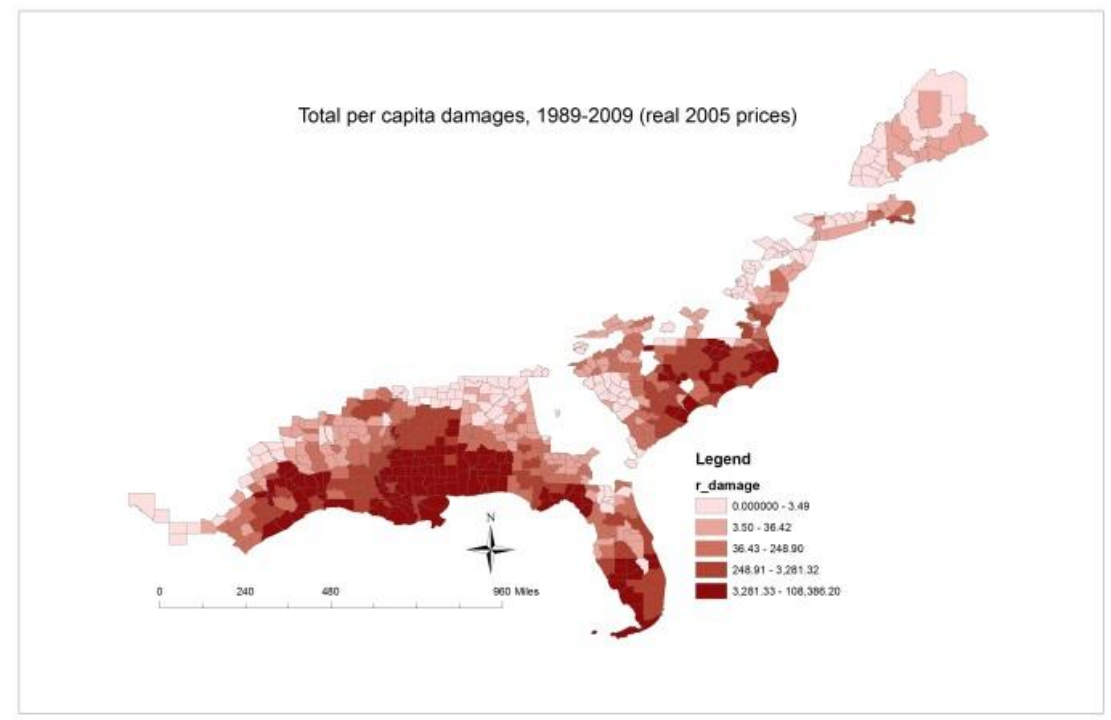

Figure 1. Hurricane-Induced Property Losses, Total for 1989-2009

Notes: This figure shows total per capita property losses in real 2005 prices induced by hurricane disasters during 1989-2009.

Source: Hazards \& Vulnerability Research Institute (2010). The Spatial Hazard Events and Losses Database for the United States, [Online Database]. Columbia, SC: University of South Carolina. Available from http://www.sheldus.org

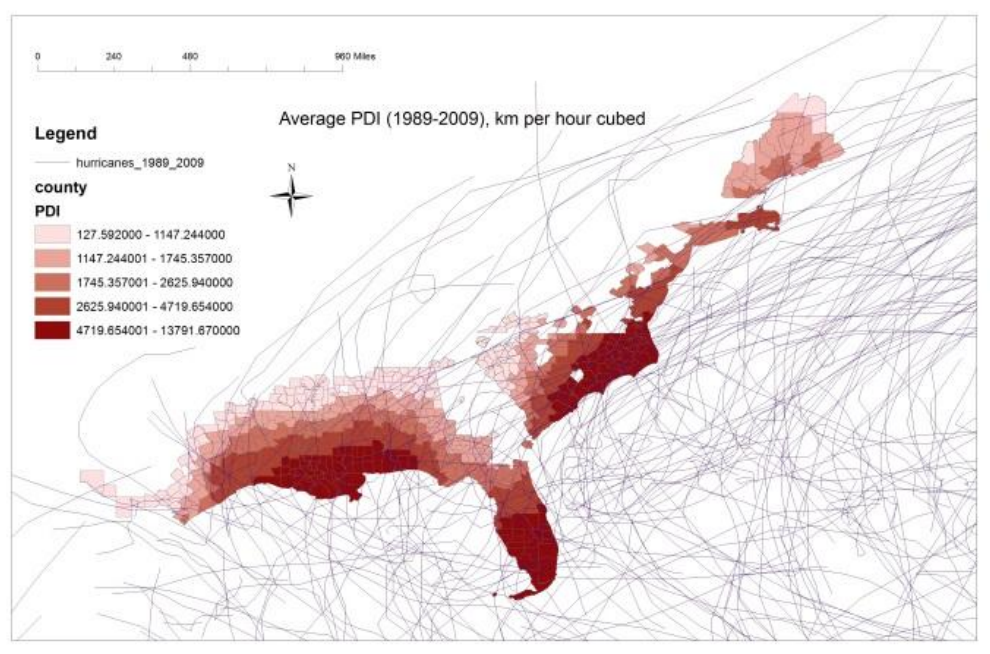

Figure 2. The Average PDI and Total Hurricane Tracks for 1989-2009

Notes: This figure shows the average PDI overlaid with the hurricane tracks during 1989-2009.

Source: Authors; NOAA, 2010. 


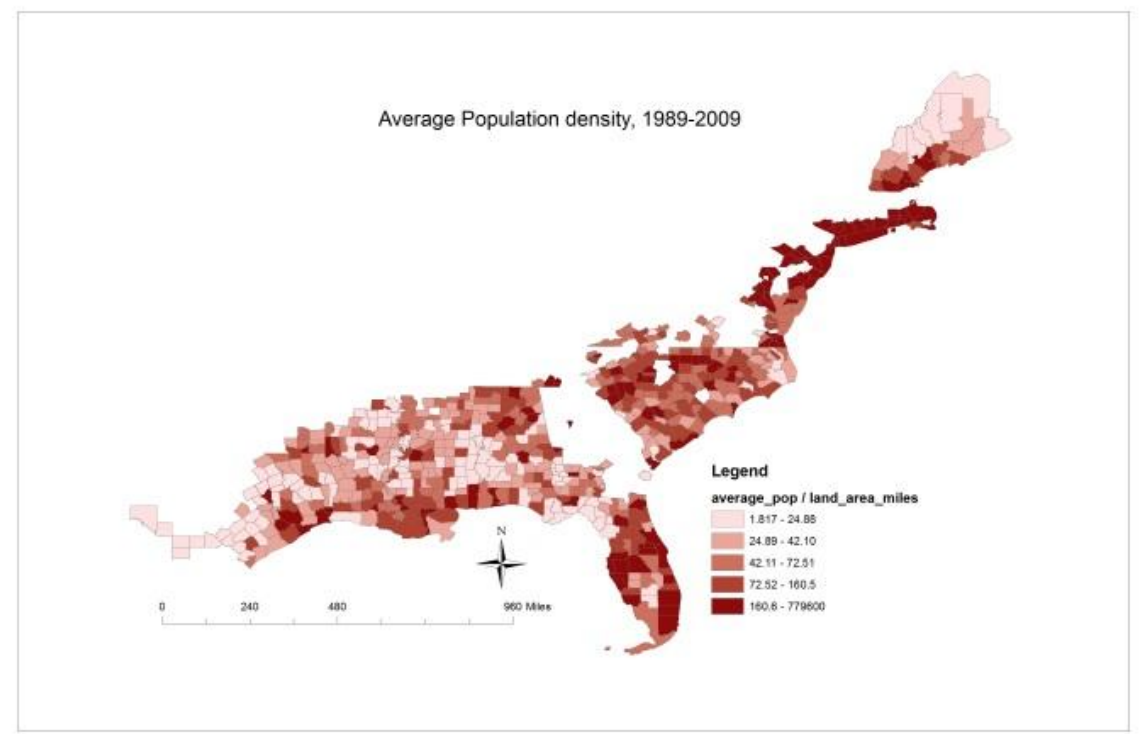

Figure 3. County Population Density, the average for the period 1989-2009

Notes: This figure shows the average population density for sample counties for the period 1989-2009. Source: BEA (2010); U.S. Census Bureau (2015a).

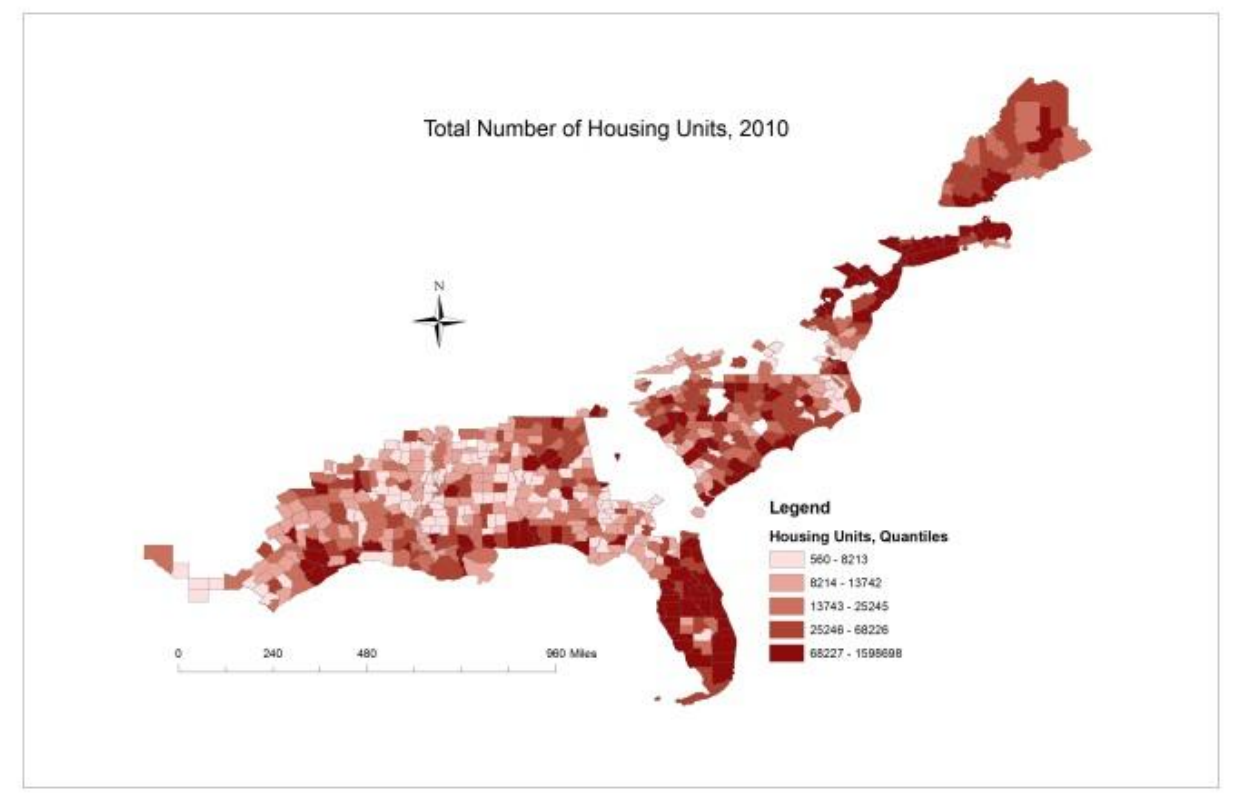

Figure 4. Total Number of Housing Units, 2010

Notes: This figure shows total number of housing units for sample counties in 2010.

Source: U.S. Census Bureau (2010b) 


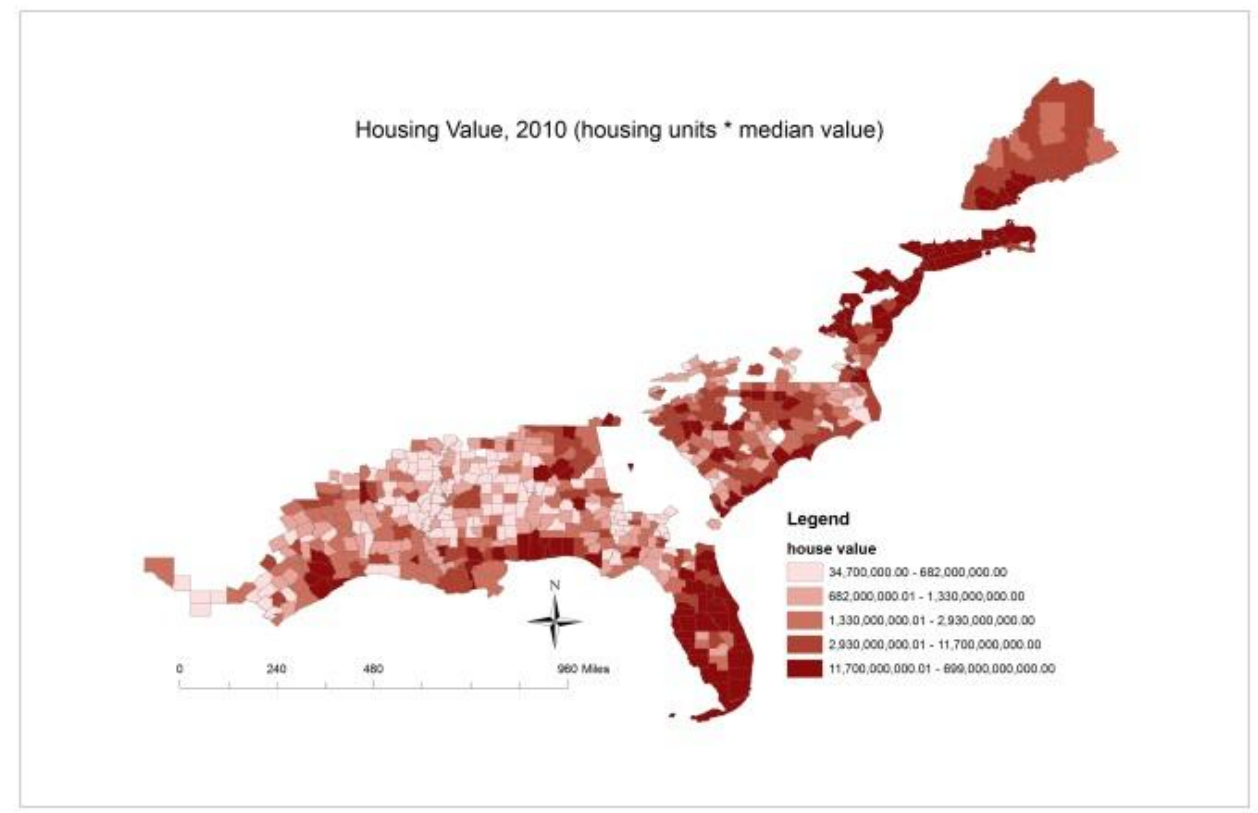

Figure 5. Housing Value, 2010

Notes: This figure shows total housing value for sample counties calculated as the product of the total number of housing units and the median house value in 2010.

Source: U.S. Census Bureau (2010b)

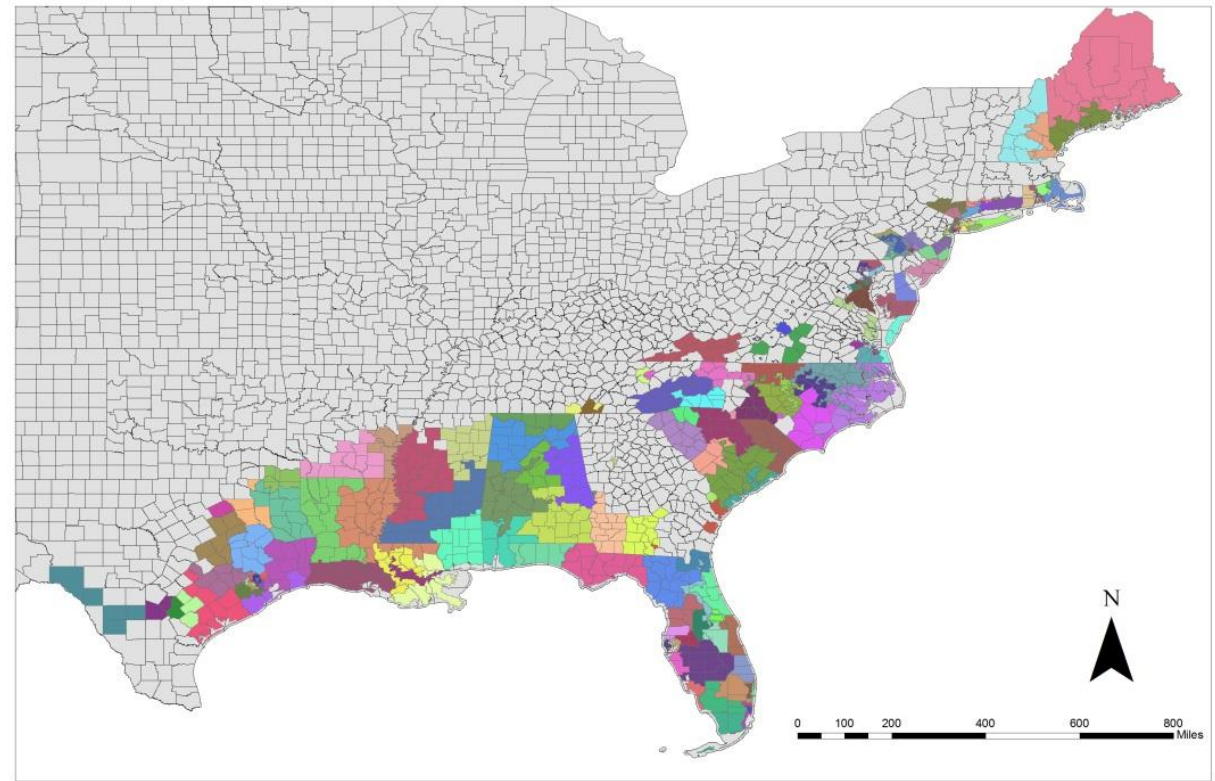

Figure 6. Congressional Districts

Notes: This figure shows congressional districts for the sample counties.

Source: U.S. Census Bureau (2015). 


\section{Tables}

Table 1. Summary Statistics

\begin{tabular}{|c|c|c|c|c|}
\hline & Mean & Std. Dev. & Min & $\operatorname{Max}$ \\
\hline Per capita property loss (real $2005 \$), \log$ & 0.4739 & 1.5613 & 0 & 11.53132 \\
\hline Per capita property loss (real $2005 \$$ ) & 138.51 & $1,595.48$ & 0 & $101,855.20$ \\
\hline Per capita income (real 2005 \$), log & 10.1118 & 0.2568 & 9.1906 & 11.5971 \\
\hline Population change, 1-year lag & -3.3852 & $4,154.082$ & $-23,9913$ & 326,205 \\
\hline Establishment change, 1-year lag & -4.5106 & 131.9186 & $-3,399$ & 2,410 \\
\hline Per capita vulnerable housing & 0.1320 & 0.0557 & 0 & 0.4393 \\
\hline cum. number of hurricanes, 1 -year lag & 1.0638 & 3.5843 & 0 & 39 \\
\hline \# of presidentially declared disasters, 1 year lag & 0.2980 & 0.5613 & 0 & 4 \\
\hline Dummy for coastal county $*$ No. of tropical storms & 0.0784 & 0.3068 & 0 & 3 \\
\hline BCEGS & 0.0244 & 0.1544 & 0 & 1 \\
\hline FEMA ex-ante programs $(\mathrm{t}-1), \log$ & 0.2354 & 0.5764 & 0 & 4.3401 \\
\hline FEMA ex-post programs $(\mathrm{t}-1), \log$ & 0.6722 & 1.6836 & 0 & 13.8894 \\
\hline Dummy for Stafford and non-Stafford committees & 0.7111 & 0.4533 & 0 & 1 \\
\hline Dummy for President and State Senate Party & 0.5503 & 0.4975 & 0 & 1 \\
\hline$\%$ voting for the independent candidate, Presidential Election & 0.0523 & 0.0669 & 0 & 0.3895 \\
\hline
\end{tabular}

Notes: The sample comprises 13,040 county by year observations. FEMA investment in adaptation types are lagged by one year. FEMA ex-ante variable represents rolling cumulative spending over the entire sample period; FEMA ex-post is the rolling cumulative spending from previous incident. Both variables are annualized. 
Table 2. Senate and House Committees Overseeing FEMA disaster and general operations

\begin{tabular}{|c|c|c|c|}
\hline Senate/House & Committee & Subcommittee & \\
\hline Senate & Appropriations & $\begin{array}{l}\text { Veterans Administration, Housing \& Urban Development, and } \\
\text { Independent Agency }\end{array}$ & Stafford \\
\hline Senate & Environment and Public Works & Clean Air, Wetlands, private property and Nuclear Safety & Stafford \\
\hline Senate & Government Affairs & Oversight of Government Management and DC & Non-Stafford \\
\hline Senate & Banking, Housing \& Urban Affairs & Housing Opportunity and Community Development & Non-Stafford \\
\hline Senate & Commerce, Science \& Transportation & Science, Technology and Space & Non-Stafford \\
\hline House & Appropriations Committee & Transportation, HUD \& Related Agencies & Stafford \\
\hline House & Transportation \& infrastructure & Water Resources \& Environment & Stafford \\
\hline House & Financial Services & Housing \& Community opportunity & Non-Stafford \\
\hline House & Science \& technology & Research \& Science Education & Non-Stafford \\
\hline
\end{tabular}




\section{Table 3. Random Effects Tobit Model First Stage Results}

\begin{tabular}{|c|c|c|}
\hline & $\begin{array}{l}\text { FEMA, ex-ante } \\
\text { (1) }\end{array}$ & $\begin{array}{c}\text { FEMA, ex-post } \\
\text { (2) }\end{array}$ \\
\hline Log of per capita income & $\begin{array}{r}1.9670 * * * \\
(0.1493)\end{array}$ & $\begin{array}{r}4.5301 * * * \\
(0.4100)\end{array}$ \\
\hline Population change & $\begin{array}{r}-0.0000 \\
(0.0000)\end{array}$ & $\begin{array}{r}0.0000 \\
(0.0000)\end{array}$ \\
\hline Establishment change & $\begin{array}{r}0.0002 * * * \\
(0.0001)\end{array}$ & $\begin{array}{r}0.0002 \\
(0.0002)\end{array}$ \\
\hline Per capita vulnerable housing & $\begin{array}{r}3.3679 * * * \\
(0.5752)\end{array}$ & $\begin{array}{r}4.3894 * * * \\
(1.6781)\end{array}$ \\
\hline Cum. No of hurricane hits (cat. 1-5), 1 year lag & $\begin{array}{r}0.0115^{* * * *} \\
(0.0021)\end{array}$ & $\begin{array}{r}0.0244 * * * \\
(0.0084)\end{array}$ \\
\hline 1 year lag of other types of disaster declaration (FEMA) & $\begin{array}{r}-0.0371 * * \\
(0.0158)\end{array}$ & $\begin{array}{r}-0.1625^{* * * *} \\
(0.0618)\end{array}$ \\
\hline Coastal county $*$ No. tropical storms & $\begin{array}{r}0.0126 \\
(0.0253)\end{array}$ & $\begin{array}{r}0.3198 * * * \\
(0.0952)\end{array}$ \\
\hline BCEGS & $\begin{array}{r}0.0144 \\
(0.0631)\end{array}$ & $\begin{array}{r}0.1596 \\
(0.2487)\end{array}$ \\
\hline Dummy for Stafford and non-Stafford committees, $\mathrm{t}-1$ & $\begin{array}{r}0.0740 * * * \\
(0.0227)\end{array}$ & $\begin{array}{r}0.2122 * * * * \\
(0.0817)\end{array}$ \\
\hline$\%$ voting for independent candidate, $\mathrm{t}-1$ & $\begin{array}{r}2.1518^{* * * *} \\
(0.3636)\end{array}$ & $\begin{array}{r}-1.2940 \\
(1.5110)\end{array}$ \\
\hline Dummy for President and State Senate Party & $\begin{array}{l}0.0747 * * * \\
(0.018901)\end{array}$ & $\begin{array}{r}0.0837 \\
(0.0699)\end{array}$ \\
\hline Constant & $\begin{array}{r}-20.6197 * * * \\
(1.5460)\end{array}$ & $\begin{array}{r}-47.2448 * * * * \\
(4.2672)\end{array}$ \\
\hline Sigma u & $\begin{array}{r}1.2810 * * * \\
(0.0517)\end{array}$ & $\begin{array}{r}2.6152 * * * \\
(0.0949)\end{array}$ \\
\hline Sigma e & $\begin{array}{r}0.6177 * * * \\
(0.0074) \\
\end{array}$ & $\begin{array}{r}2.3531 * * * \\
(0.0316) \\
\end{array}$ \\
\hline $\begin{array}{l}\mathrm{N} \\
\text { Log-likelihood }\end{array}$ & $\begin{array}{r}13,040 \\
-6,064.41\end{array}$ & $\begin{array}{r}13,040 \\
-10,765.01\end{array}$ \\
\hline Rho & 0.8113 & 0.5526 \\
\hline
\end{tabular}

Notes: The dependent variables are the log value of per capita FEMA cumulative spending on ex-ante over all sample period and cumulative FEMA spending on ex-post programs from the most recent incident. Both variables are annualized. Column names correspond to two different adaption variables that are used as the dependent variable in the Random Effects Tobit model given by equation (7) in the text. Includes year fixed effects and panel means of time varying variables. A dummy variable for Stafford and non-Stafford committees is the state-level instrument. Both the percent voting for independent candidate during the most recent presidential election and a dummy variable for President and State Senate Party are county-level instruments. Bootstrapped standard errors are given in parenthesis and are clustered by congressional district, based on 1000 replications.

Source: Author calculations.

*** Significant at the 1 percent level.

** Significant at the 5 percent level.

* Significant at the 10 percent level. 


\section{Table 4. Random Effects and Correlated Random Effects Tobit Model Results}

\begin{tabular}{|c|c|c|}
\hline & CRE & CF CRE \\
\hline & $(1)$ & $(2)$ \\
\hline \multirow[t]{2}{*}{ Log of per capita income } & $10.0671^{* * * *}$ & $12.4165^{* * *}$ \\
\hline & (3.3184) & (3.2340) \\
\hline \multirow{2}{*}{ Population change } & 0.0000 & 0.0000 \\
\hline & $(0.0000)$ & $(0.0000)$ \\
\hline \multirow[t]{2}{*}{ Establishment change } & $0.0012^{* *}$ & $0.0012 * *$ \\
\hline & $(0.0005)$ & $(0.0005)$ \\
\hline \multirow[t]{2}{*}{ Per capita vulnerable housing } & $35.2860 * * *$ & $33.8321 * * *$ \\
\hline & (11.0405) & (9.8394) \\
\hline \multirow[t]{2}{*}{ Cum. No of hurricane hits (cat. 1-5) } & 0.0138 & 0.0250 \\
\hline & $(0.0265)$ & $(0.0256)$ \\
\hline \multirow[t]{2}{*}{1 year lag of other types of disaster declaration } & -0.3672 & -0.4015 \\
\hline & $(0.2804)$ & $(0.2767)$ \\
\hline \multirow{2}{*}{ Coastal county $*$ No. tropical storms } & $2.5172 * * *$ & $2.5404 * * *$ \\
\hline & $(0.3143)$ & $(0.2939)$ \\
\hline \multirow[t]{2}{*}{ BCEGS } & 0.0494 & 0.3361 \\
\hline & $(0.6106)$ & $(0.5932)$ \\
\hline \multirow{2}{*}{ FEMA, ex-ante } & $-0.6118^{* *}$ & $-1.1022 * * *$ \\
\hline & $(0.2991)$ & $(0.4116)$ \\
\hline \multirow{2}{*}{ FEMA, ex-post } & -0.1092 & $-0.6319 * *$ \\
\hline & $(0.0986)$ & $(0.2673)$ \\
\hline \multirow[t]{2}{*}{ Generalized residuals, FEMA ex-ante } & & $0.4007 *$ \\
\hline & & $(0.2326)$ \\
\hline \multirow[t]{2}{*}{ Generalized residuals, FEMA ex-post } & & $0.3524 * *$ \\
\hline & & $(0.1642)$ \\
\hline \multirow[t]{2}{*}{ Constant } & 8.0876 & -3.2190 \\
\hline & $(7.6679)$ & $(8.7140)$ \\
\hline \multirow[t]{2}{*}{ Sigma u } & $1.9463 * * *$ & $1.9682 * * *$ \\
\hline & $(0.1761)$ & $(0.1680)$ \\
\hline \multirow[t]{2}{*}{ Sigma e } & $4.6400^{* * *}$ & $4.6215^{* * *}$ \\
\hline & $(0.2203)$ & $(0.2206)$ \\
\hline $\mathrm{N}$ & 13,040 & 13,040 \\
\hline Log-likelihood & $-7,667.53$ & $-7,635.27$ \\
\hline Rho & 0.1496 & 0.1535 \\
\hline
\end{tabular}

Notes: The dependent variable is the log value of per capita property loss. Includes year fixed effects and the means of all time varying model co-variates. Column (1) reports estimates of the correlated random effects tobit model from equation (4) in the text. Column (2) reports coefficient estimates of the control function correlated random effects tobit model, given by equation (6) in the text. Generalized residuals control for endogeneity of FEMA ex-ante and FEMA ex-post adaptation variables in the model, respectively, and are obtained from the regression model defined in equation (7) in the text. Bootstrapped standard errors are given in parenthesis and are clustered by congressional district, based on 1000 replications.

Source: Author calculations.

*** Significant at the 1 percent level.

** Significant at the 5 percent level.

* Significant at the 10 percent level. 
Table 5. Conditional and Unconditional Marginal Effects

\begin{tabular}{lcc}
\hline \hline & & \\
\cline { 2 - 3 } & $(1)$ & $(2)$ \\
\hline FEMA, ex-ante & $-0.2071^{* * *}$ & $-0.1674 * * *$ \\
& $(0.0768939)$ & $(0.0631)$ \\
FEMA, ex-post & $-0.1187^{* *}$ & $-0.0960 * *$ \\
& $(0.0517)$ & $(0.0427)$ \\
\hline
\end{tabular}

Notes: Marginal effects are obtained using the delta method and are estimated at the sample means of all regression variables. Columns (1) and (2) are the conditional and unconditional marginal effects of the FEMA program variables, respectively, corresponding to the coefficients presented in column (2) of Table 4; standard errors are given in parenthesis Source: Author calculations.

*** Significant at the 1 percent level.

** Significant at the 5 percent level.

* Significant at the 10 percent level. 
Table 6: Cragg's Double Hurdle Model

\begin{tabular}{|c|c|c|}
\hline & $\begin{array}{c}(1) \\
\text { Tier I }\end{array}$ & $\begin{array}{c}(2) \\
\text { Tier } 2\end{array}$ \\
\hline \multirow[t]{2}{*}{ Log of per capita income } & $1.9517 * * *$ & $15.0994 * * *$ \\
\hline & $(0.4006)$ & $(2.7176)$ \\
\hline \multirow[t]{2}{*}{ Population change } & 0.0000 & 0.0000 \\
\hline & $(0.0000)$ & $(0.0001)$ \\
\hline \multirow[t]{2}{*}{ Establishment change } & 0.0001 & $0.0056^{* * * *}$ \\
\hline & $(0.0001)$ & $(0.0017)$ \\
\hline \multirow[t]{2}{*}{ Per capita vulnerable housing } & $5.8947 * * *$ & 4.1724 \\
\hline & (1.4711) & (11.0244) \\
\hline \multirow[t]{2}{*}{ Cum. No of hurricane hits (cat. 1-5) } & $0.0103^{* * *}$ & 0.0309 \\
\hline & $(0.0039)$ & $(0.0200)$ \\
\hline \multirow{2}{*}{1 year lag of other types of disaster declaration } & -0.0360 & $-0.6199 *$ \\
\hline & $(0.0288)$ & $(0.3279)$ \\
\hline \multirow[t]{2}{*}{ Coastal county $*$ No. tropical storms } & $0.6270^{* * *}$ & $1.6841 * * *$ \\
\hline & $(0.0516)$ & $(0.2214)$ \\
\hline \multirow{2}{*}{ BCEGS } & $0.3282 *$ & 0.4985 \\
\hline & $(0.1778)$ & $(0.9267)$ \\
\hline \multirow{2}{*}{ FEMA, ex-ante } & $-0.2322 * * *$ & 0.2309 \\
\hline & $(0.0736)$ & $(0.4360)$ \\
\hline \multirow[t]{2}{*}{ FEMA, ex-post } & -0.0430 & $-1.0046^{* * *}$ \\
\hline & $(0.0364)$ & (0.2235) \\
\hline \multirow[t]{2}{*}{ Generalized residuals, FEMA ex-ante } & $0.0951 * *$ & -0.4313 \\
\hline & $(0.0477)$ & $(0.2986)$ \\
\hline \multirow{2}{*}{ Generalized residuals, FEMA ex-post } & 0.0227 & $0.6369 * * *$ \\
\hline & $(0.0215)$ & $(0.1539)$ \\
\hline \multirow[t]{2}{*}{ Constant } & 0.1544 & $21.6280^{*}$ \\
\hline & $(1.2366)$ & $(12.3128)$ \\
\hline \multirow[t]{2}{*}{ sigma } & & $3.2148 * * *$ \\
\hline & & (0.1047) \\
\hline Log-likelihood & $-7,387.54$ & \\
\hline $\mathrm{N}$ & 13,040 & \\
\hline \multicolumn{3}{|c|}{$\begin{array}{l}\text { Notes: Tier } 1 \text { estimates the correlated random effects Probit model in which the dependent variable is binary and equals one for } \\
\text { positive damages. In the second Tier, the dependent variable is the log value of per capita property loss. Includes year fixed effects } \\
\text { and panel means of all time varying co-variates. Generalized residuals control for endogeneity of FEMA ex-ante and FEMA ex-post } \\
\text { variables in the model, respectively and are obtained from the regression model defined in equation (7) in the text. Robust standard } \\
\text { errors are given in parenthesis and are clustered by congressional district. }\end{array}$} \\
\hline
\end{tabular}


Table 7. Distribution of storm-level predicted total and actual damages

\begin{tabular}{lcc}
\hline & $\begin{array}{c}\text { Predicted total damage } \\
\text { From model in Table 4 (2) } \\
(\log )\end{array}$ & $\begin{array}{c}\text { Actual SHELDUS storm-level } \\
\text { damages (log) }\end{array}$ \\
\hline $10^{\text {th }}$ percentile & 11.5102 & 10.4829 \\
$25^{\text {th }}$ percentile & 12.6039 & 11.8175 \\
Median & 14.0046 & 14.4606 \\
Mean & 14.1045 & 14.6911 \\
$75^{\text {th }}$ percentile & 15.3399 & 17.1412 \\
$90^{\text {th }}$ percentile & 16.7141 & 19.3370 \\
\hline
\end{tabular}

